\title{
The first record of Late Jurassic crossognathiform fishes from Europe and their phylogenetic importance for teleostean phylogeny
}

\author{
Gloria Arratia $^{*}, 1$ and Helmut Tischlinger ${ }^{2}$ \\ ${ }^{1}$ Biodiversity Research Center, The University of Kansas, Dyche Hall, Lawrence, Kansas 66045-7561, U.S.A. \\ E-mail: garratia@ku.edu \\ ${ }^{2}$ Tannenweg 16, 85134 Stammham, Germany. E-mail: htischlinger@online.de
}

\begin{abstract}
Received 8 December 2009

Accepted 15 February 2010

Published 3 August 2010

\section{Key Words}

Crossognathiform fishes

Bavarichthys n. gen.

morphology

phylogeny

Late Jurassic

Solnhofen Limestones

The Late Jurassic Bavarichthys incognitus, n. gen. n. sp. from Ettling, Bavaria, is described. The new species represents the oldest record of a crossognathiform in Europe and together with Chongichthys from the Oxfordian of South America stands at the basal levels of a clade including crossognathids and pachyrhizodontoids. In addition, the new fish represents the first record of a crossognathiform in the Solnhofen Limestones. The new genus is characterized by numerous features such as the presence of infraorbitals 1-3 independent and 4+5 fused; two supramaxillary bones present; supramaxilla 2 considerably shorter than supramaxilla 1 and lacking an antero-dorsal process; well-developed series of epineural, epicentral and epipleural intermuscular bones; parhypural and hypurals 1 and 2 partially fused to each other; a series of epaxial basal fulcra; and a few, elongate fringing fulcra associated with the dorsal leading margin of caudal fin.
\end{abstract}

Germany

\section{Introduction}

The Crossognathiformes is an extinct fish order erected by Taverne (1989) to contain the crossognathids and the pachyrhizodontoids, and until recently, considered a typical Cretaceous taxon. However, recent studies of the group have shown that the Jurassic family Varasichthyidae is the sister group of pachyrhizodontoids plus crossognathids extending the range of the group to the Oxfordian in the Jurassic (Arratia 2008a). As pointed out by Arratia (2008a), the history of the group is complicated since over a century several families and numerous genera and species have been described, many now considered synonyms (for details see Agassiz 1843; Dixon 1850; Pictet 1858; Cope 1872; Loomis 1900; Woodward 1901; Forey 1977; Patterson \& Rosen 1977; Teller-Marshall \& Bardack 1978; Taverne 1980, 1989; Maisey 1991a, b; Patterson 1993).

Currently, crossognathiforms are known from about five extinct families (e.g., Chongichthyidae, Crossognathidae, Notelopidae, Pachyrhizodontidae, and Varasichthyidae) and numerous genera. Among these, chong- ichthyids are known from one genus (Chongichthys) from the Oxfordian of northern Chile, whereas varasichthyids are known from five genera most recovered in localities in the Southern Hemisphere (Arratia \& Schultze 1985, 1999). Among these genera, Bobbichthys, Domeykos, Protoclupea, and Varasichthys are from the Oxfordian of northern Chile, whereas the Cuban Luisichthys is Late Jurassic in age. Crossognathids are known from two genera, Crossognathus and Apsopelix. The Early Cretaceous genus Crossognathus, with two species, has been recovered in France, Germany, and Romania (Taverne 1989; Patterson 1993; Cavin \& Grigorescu 2005), whereas the Late Cretaceous Apsopelix anglicus has a broader geographical distribution including North America (e.g., Colorado, Kansas, South Dakota), England, and France (Teller-Marshall \& Bardack 1978). In contrast, pachyrhizodontoids are known from many species placed in at least two families, i.e., Notelopidae and Pachyrhizodontidae, with a wide geographical and temporal distribution. The oldest pachyrhizodontoid is known from the Upper Jurassic of Chile (Arratia \& Schultze 1999); however, numerous pachy-

* Corresponding author 
rhizodontoids from Brazil are Early Cretaceous (Apitan) in age (e.g., Notelops brama and Rhacolepis buccalis) (see Agassiz 1833-1844; Jordan \& Branner 1908; Silva Santos \& Valença 1968; Dunkle 1940; Forey 1977; Maisey 1991a, 1991b) and the youngest from the Paleogene (Eocene, Lutetian) of Monte Bolca (Platinx macropterus) (Taverne 1980; Patterson 1993). Recent new discoveries of Cretaceous pachyrhizodontids in the Albian of Mexico (Michin csernai: Alvarado-Ortega et al. 2008), and in the Campanian-Maastrichtian of Nardò (Nardopiscis cavini: Taverne 2008), and in the Lower Turonian of Canada (Aquilopiscis wilsoni: Cumbaa \& Murray 2008) continue to expand the knowledge base of the group. According to the current evidence, the oldest known crossognathiforms are members of the Late Jurassic families Varasichthyidae and Chongichthyidae.

The new fish described here is the first record of a crossognathiform in the Upper Jurassic Solnhofen Limestones of Bavaria, Germany. It was recovered from a poorly known locality - Ettling - from where other fishes (e.g., Thrissops; Tischlinger 1998) showing exceptional preservation (e.g., color patterns) are found. Although numerous fishes belonging to different actinopterygian taxa have been collected in Ettling recently (Ebert \& Kölbl-Ebert 2008), only two fish taxa have been formally described, e.g., a euteleost (Orthogonikleithrus hoelli Arratia, 1997) and an aspidorhynchiform (Aspidorhynchus sanzenbacheri Brito \& Ebert, 2009). In addition to the description of the new fish, information about the locality, its possible age, and information on certain methods facilitating the study of the fossils is provided.

\section{Locality, geology and possible age}

\section{The Fossil-Lagerstätte of Ettling}

The little village of Ettling is part of the market town of Pförring and is situated on the southernmost rim of the southern Frankonian Alb. Here the Late Jurassic tableland declines slightly southwards to the Danube River and henceforward dips completely under the Molasse basin of the Alps. The Plattenkalk quarry of Ettling is located at the western outskirts of the village. During the past decades extensive quarrying for public works has taken place. Originally, the layers supposedly did not contain noteworthy fossils (Patzelt 1963). Beginning in 1990, some private collectors discovered a few fossils, but due to their poor preservation not much interest was gathered (Tischlinger 1992), but in 1996 this changed when more remains of fishes were assembled by collectors. After a painstaking and extremely time consuming preparation, these specimens revealed an outstanding state of preservation (Tischlinger 1998). Since that time, private collectors periodically have recovered specimens of fishes, accompanied by concurrent quarrying operations performed for sporadic public works.
The discovered fossils demonstrated an exceptional concentration and a great diversity of fishes along with an unusual quality of preservation. Many of the finds are very fragile or heavily broken, demanding extraordinary diligence and great preparation skill. Many collectors are overextended by the preparation requirements of these fossils. Therefore, a number of these specimens were donated or sold to the Jura-Museum Eichstätt by private collectors, including collections from Mr. R. Höll, so that the first description of a fish from this locality (Orthogonikleithrus hoelli) could be published (Arratia 1997). Consequently, research activities by staff members of the Eichstätt Jura-Museum started and in summer 2007, the Ettling quarry became an official excavation site of the Jura-Museum Eichstätt in accordance with the quarry owner and the market town of Pförring (Ebert \& Kölbl-Ebert 2008).

\section{Geological setting}

Ettling is located at the north-eastern margin of a comparatively small depression with bedded carbonate rocks, the Hartheim Basin ("Hartheimer Wanne"), surrounded by massive dolomites which were formerly interpreted as algal-sponge bioherms. According to new data, the dolomites might also consist of partially thickbedded calcareous sands. The Hartheim Basin is part of the Frankonian-South Bavarian Carbonate Platform (Meyer \& Schmidt-Kaler 1989), which developed in the Kimmeridgian (Meyer \& Schmidt-Kaler 1983). According to Patzelt (1963) and Meyer \& Schmidt-Kaler (1989) the sediment filling of the Hartheim Basin comprises Upper Kimmeridgian and mainly Lower Tithonian strata, that is, according to the former German regional stratigraphic subdivision of the Franconian Alb, from Malm Epsilon 2 ("setatus Zone") up to Malm Zeta 3.

The limits of the Hartheim Basin is caused by the current state of erosion (Fig. 1); originally the basin might have been much larger. To the east, it is bordered by beds of coral-reef detritus of the Marching reefcomplex (Meyer \& Schmidt-Kaler 1983).

\section{Facies, stratigraphy and possible age}

The present section at the excavation site of Ettling exposes a $28 \mathrm{~m}$ thick series of Plattenkalk (Ebert \& Kölbl-Ebert 2008). Two prominent slump units are intercalated. Between the $1 \mathrm{~m}$ thick lower slump unit adjacent to the actual quarry bottom and the striking and heavily folded 1.5 to $2 \mathrm{~m}$ thick upper slump unit there are $10 \mathrm{~m}$ thick laminated limestones with a prominent internal microbedding. The distance of these laminae measures 0.5 to $4 \mathrm{~mm}$. The single laminae normally split easily. Dried up layers or those exposed to freezing and thawing occasionally crumble easily when touched. Calcareous fine-layered marls are irregularly intercalated as well as thicker Plattenkalk beds up to some $\mathrm{cm}$ without discernible lamination. Following above the upper slump unit, thick-bedded Plattenkalk 


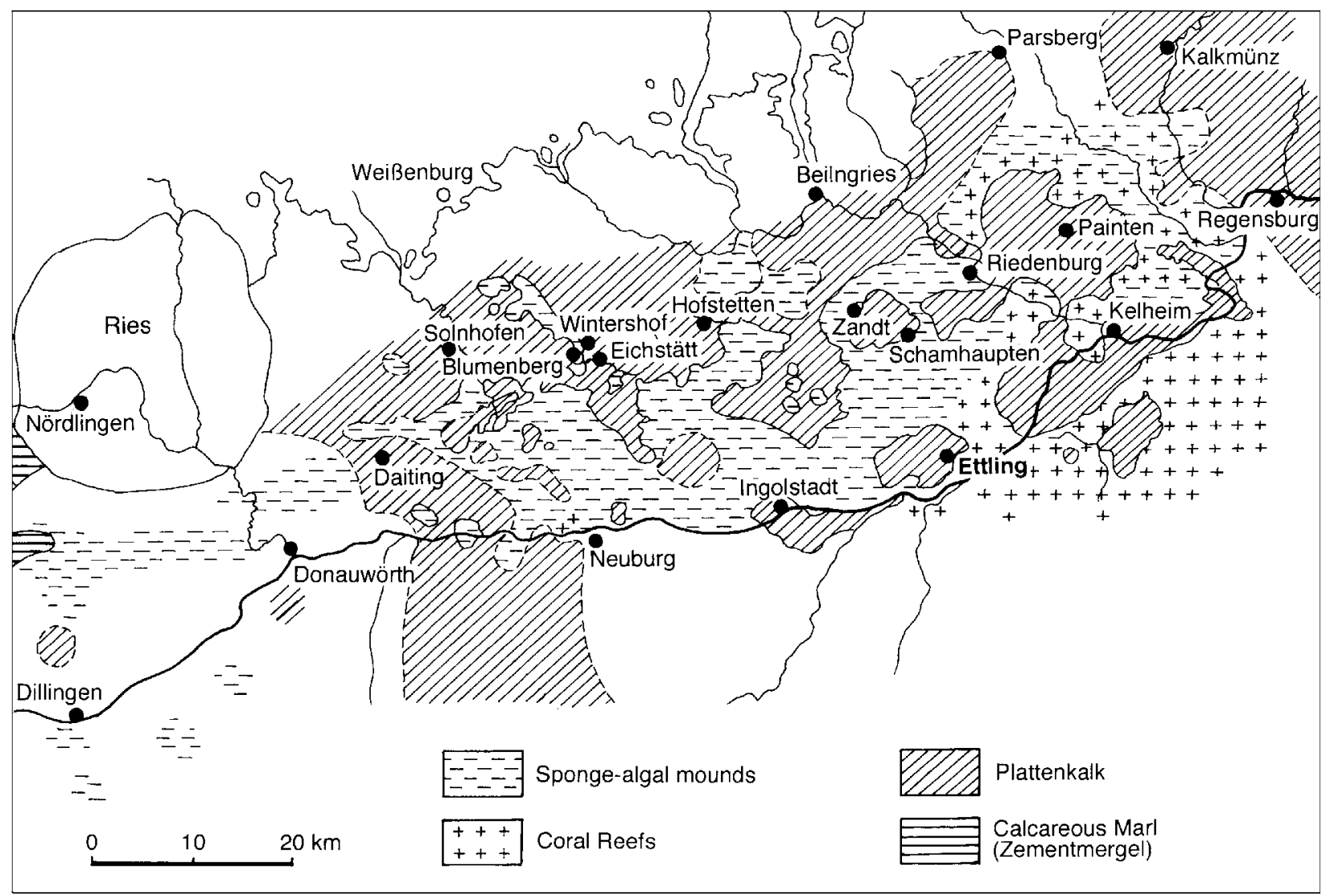

Figure 1. Distribution of Plattenkalk basins and reef areas in the southern Franconian Alb during Early Tithonian (slightly modified from Viohl 1996). The crossognathiform fish described herein was recovered in Ettling.

beds appear, each separated by intercalated fine marly clay layers. These sometimes reach a thickness of up to $80 \mathrm{~cm}$ and resemble the famous lithographic Plattenkalk of Solnhofen and Langenaltheim. Fossils, particularly fishes, occur in the whole section but appear to be more commonly found within the lower Plattenkalk beds.

\begin{tabular}{|c|c|c|c|c|}
\hline Age & $\begin{array}{l}\text { former regional } \\
\text { stratigraphic } \\
\text { subdivision }\end{array}$ & $\begin{array}{c}\text { Patzelt (1963) } \\
\text { Schnitzer (1965) }\end{array}$ & Zeiss (1977) & $\begin{array}{c}\text { Meyer } \\
(2001,2003)\end{array}$ \\
\hline $\begin{array}{l}\text { Early Tithonian } \\
\text { (probably } \\
\text { comparable to } \\
\text { moernsheimensis }\end{array}$ & $\begin{array}{l}\text { Malm } \\
\text { Zeta } 3\end{array}$ & & & $\begin{array}{l}\text { Hartheimer } \\
\text { Bankkalke, } \\
\text { Malm Zeta 3H } \\
\text { > } 15 \mathrm{~m}\end{array}$ \\
\hline $\begin{array}{l}\text { (probably } \\
\text { comparable to } \\
\text { rueppellianus }\end{array}$ & $\begin{array}{l}\text { Malm } \\
\text { Zeta } 2 \mathrm{~b} \\
\text { (Upper Solnhofen } \\
\text { Formation) }\end{array}$ & $\begin{array}{c}\text { Untere } \\
\text { Bankkalke } \\
>15 \mathrm{~m}\end{array}$ & $\begin{array}{l}\text { Hepberg- } \\
\text { Denkendorf } \\
\text { member }\end{array}$ & $\begin{array}{c}\text { Kelsbach- } \\
\text { Schiefer, } \\
\text { Malm Zeta } 2 \mathrm{~K} \\
10 \mathrm{~m}\end{array}$ \\
\hline $\begin{array}{c}\text { (probably } \\
\text { comparable to }\end{array}$ & $\begin{array}{c}\text { Malm } \\
\text { Zeta 2 a } \\
\text { (Lower Solnhofen } \\
\text { Formation) }\end{array}$ & $\begin{array}{c}\text { Kelsbach- } \\
\text { Schiefer } \\
10 \mathrm{~m}\end{array}$ & $\begin{array}{l}\text { Kelsbach } \\
\text { Member }\end{array}$ & \\
\hline & $\begin{array}{l}\text { Malm } \\
\text { Zeta } 1\end{array}$ & & & \\
\hline $\begin{array}{c}\text { Late } \\
\text { Kimmeridgian }\end{array}$ & $\begin{array}{l}\text { Malm } \\
\text { Epsilon }\end{array}$ & & & \\
\hline
\end{tabular}

Figure 2. Lithological subdivision of the strata of Ettling. Up to now the Kelsbach-Schiefer (Kelsbach Member) has yielded most of the fishes. 
For the time being the sequence of Ettling is exclusively subdivided lithostratigraphically since a biostratigraphical subdivision is not yet possible (Fig. 2). Patzelt (1963) and Schnitzer (1965) classified the $10 \mathrm{~m}$ thick Plattenkalk between the lower slump and the upper slump unit as "Kelsbach-Schiefer". They grouped it within the "Malm Zeta 2 a", possibly comparable in age with the lower Solnhofen Formation of Eichstätt (Lower Tithonian, hybonotum Zone, riedense Subzone; Schweigert 2007). According to Patzelt (1963) and Schnitzer (1965) the Plattenkalk beds above the upper slum unit are part of their "Untere Bankkalke" of the Hartheim Basin and belong to the Malm Zeta $2 \mathrm{~b}$ of the upper Solnhofen Formation (possibly comparable to the Plattenkalk of Solnhofen / Langenaltheim: Lower Tithonian, hybonotum Zone, ruppellianus Subzone; Schweigert 2007). Zeiss (1977) also grouped the Plattenkalk between the lower and the upper slump unit within the lower Solnhofen Formation, referring to it as "Kelsbach member". After Meyer $(2001,2003)$ the "Kelsbach-Schiefer" and the adjacent beds are characteristic members of the Hartheim Basin; he suggested a younger age. He placed the "Kelsbach-Schiefer" within his "Malm Zeta $2 \mathrm{~K}$ " (comparable to the upper part of the Solnhofen Formation) and the $15 \mathrm{~m}$ thick beds above the upper slump unit to the "Malm Zeta $3 \mathrm{H}$ " (comparable to the Mörnsheim Formation: Lower Tithonian, hybonotum Zone, moernsheimensis Subzone; cf. Schweigert 2007). To present date, the Plattenkalk of Ettling have not yielded determinable ammonites. Therefore a detailed biostratigraphical analysis is missing. Schweigert (2007) assumed that the environment was too shallow and thus unfavourable for ammonites.

\section{Material and methods}

For a list of material used in comparative studies see Arratia (2008a, p. 72). Specimens cited here are deposited in the following institutions: FMNH, Field Museum of Natural History, Chicago, IL., USA; KUVP, Division of Vertebrate Paleontology, Natural History Museum, University of Kansas, Lawrence, KS, USA; JME, Jura-Museum Eichstätt, Eichstätt, Germany.

The fish described here was studied using both white and ultraviolet lights. Arratia executed the drawings of the fish with the help of Leica and Wild stereomicroscopes with camera lucida attachment.

\section{Ultraviolet light investigations}

Most skeletal remains of fossils and sometimes slightly mineralized soft parts from the Upper Jurassic plattenkalks of southern Franconia are fluorescent under ultraviolet radiation. During the last 10 years ultraviolet investigation techniques and ultraviolet-light photography of Solnhofen fossils have been improved considerably, using powerful UV lamps and new photographic documentation techniques (Tischlinger 2002, 2005).

In the majority of cases morphological details of skeletal remains as well as soft parts can be more precisely investigated in ultraviolet light than in visible light. Delicate skeletal elements including different bony components (e.g., ribs, intermuscular bones; Figs 3A-C and below) and remains of soft parts are poorly or not discernable in visible light but shine conspicuously under filtered UV. The technique can be used to show up hidden bony sutures, and to separate bones or soft parts from the underlying matrix or each other. Fishes from Ettling sometimes show remains of original colour patterns which are occacionally visible in natural light but revealing subtle details under UV. For our investigations on Ettling material we exclusively use UVA lamps with a wavelength of 365-366 nanometers.

\section{UV-Photography}

Sometimes essential details of bones and soft parts can exclusively be demonstrated by ultraviolet-light photography due to the fact that the researcher will not be able to differentiate tiny structures and differences in colour and composition under ultraviolet light with the naked eye or with the microscope. The application of different filters allows a selective visualisation of peculiar fine structures. In most cases a selection of different colour correction filters is necessary. Each limestone slab and bone or tissue will react differently to different light wavelengths and is captured differently with varying exposures and filters. The right combination is needed to highlight the area of interest. The optimum filtering and exposure time has to be tested in a series of experiments (Tischlinger 2002). The number and combination of filters varies greatly and exposure times vary between $10 \mathrm{sec}-$ onds and 10 minutes, depending on the nature of the fossil material and the magnification, intensity, and incident angle of the ultraviolet lamps. Filtering works optimally with analogue photography and slide film although digital cameras can be used, too.

\section{Phylogenetic analyses}

Although a detailed study of the phylogenetic relationships of the new fish is not a goal of this paper, its phylogenetic position was investigated using cladistic principles (Hennig 1966). The phylogenetic analyses were conducted using PAUP (Phylogenetic Analysis Using Parsimony) software (version 4.0b10; Swofford 2005) on a Macintosh computer. All characters are unweighted, unordered, and considered simple and independent of one another. Most characters and taxa of Arratia (2008a) are used in this study (see Appendix). Two new taxa were added, the Late Jurassic Bavarichthys n.gen. and the Recent characiform Brycon. The outgroups used to polarize characters includes Amia calva and $\dagger$ A. pattersoni, $\dagger$ Aspidorhynchus, $\dagger$ Belonostomus, $\dagger$ Hypsocormus, Lepisosteus, $\dagger$ Mesturus, $\dagger$ Obaichthys, $\dagger$ Pachycormus, and $\dagger$ Vinctifer. One analysis was performed using a hypothetical ancestor as outgroup.

For the coding of crossognathiforms, the following literature was used:

Apsopelix anglicus: Teller-Marshall \& Bardack (1978), Patterson \& Rosen (1977), and Arratia's own observations on specimens deposited at FMNH and KUVP. Chongichthys dentatus: Arratia (1982, 1986, 1997) and observations on material recently collected in northern Chile by G. Arratia and H.-P. Schultze. Crossognathus sabaudianus: Wenz (1965), Patterson \& Rosen (1977), and Taverne (1989). Goulmimichthys arambourgi: Cavin (2001). Rhacolepis buccalis: Forey (1977) and Maisey (1991a). Notelops brama: Forey (1977) and Maisey (1991b). 

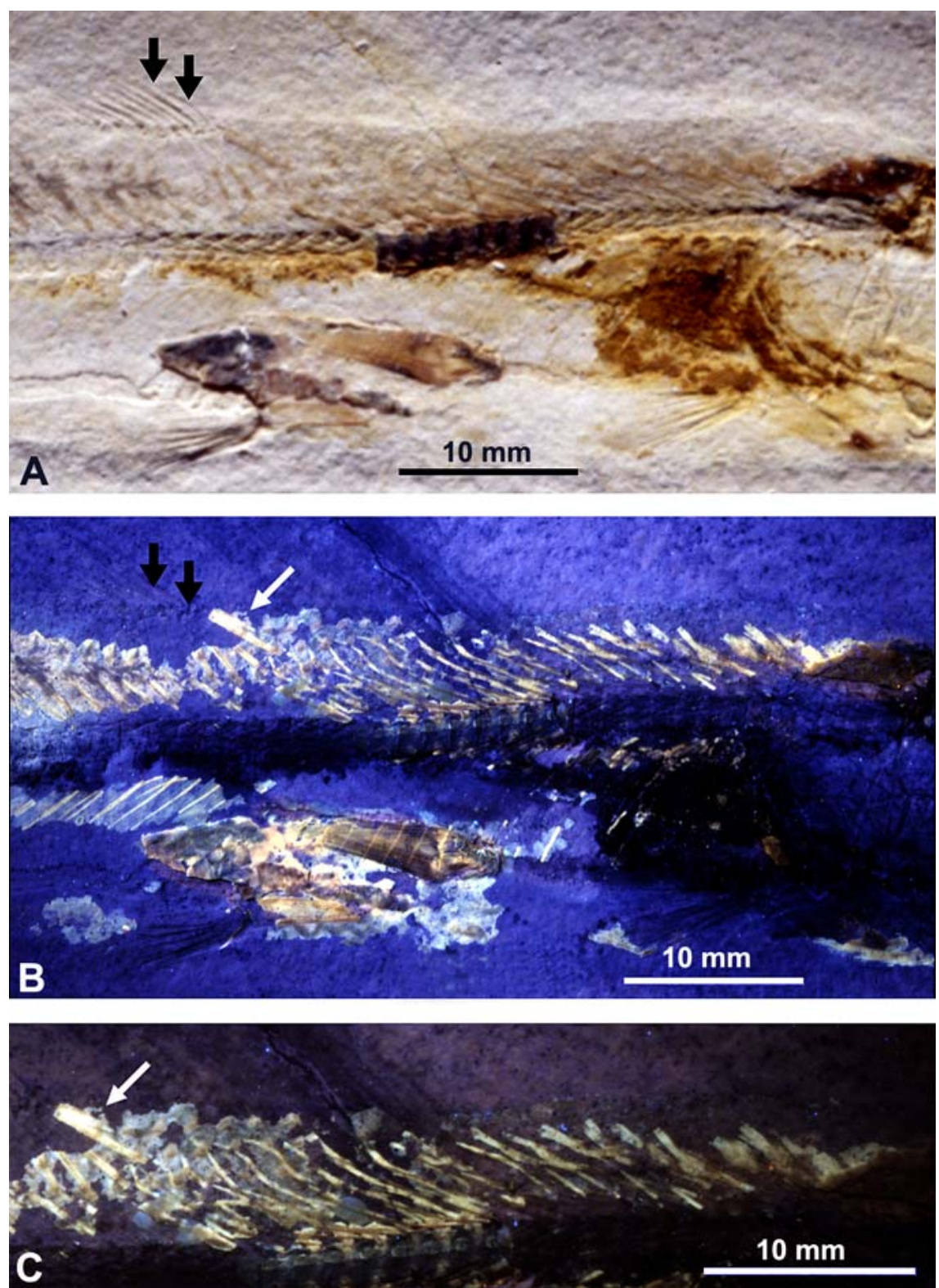

Figure 3. Observation of the crossognathiform fish described here (JME SOS 4934b) under different light conditions. A. Section of the body just behind the head under white light. Double arrows point to the beginning of dorsal fin. B. Same region of the body as illustrated in A, but under ultraviolet light. Note the first dorsal pterygiophore (indicated by a white arrow) and the series of supraneural bones that are now visible under ultraviolet light. C. Enlargement of a section illustrated in B showing details of the first dorsal pterygiophore (indicated by a white arrow).

\section{Systematic paleontology}

\author{
Actinopterygii Cope, 1887 \\ Teleostei sensu Arratia, 1999 \\ Crossognathiformes sensu Arratia, 2008a \\ Family Indeterminate
}

\section{Bavarichthys n. gen.}

Diagnosis (based on a unique combination of characters. Uniquely derived characters among crossognathiforms are identified with an asterisk [ $\left.{ }^{*}\right]$ ). Crossognathiforms with a large head about $30 \%$ in standard length and a characteristically elongate snout, more than $25 \%$ in head length [ $\left.{ }^{*}\right]$. Large suprascapular bone. Infraorbital series with infraorbitals $1-3$ independent and $4+5$ fused [ $\left.{ }^{*}\right]$. Infraorbital 2 with a sharp postero-ventral lamina. Broadly expanded infraorbitals 3 and $4+5$. Two supramaxillary bones. Long supramaxilla 1 , almost double of length of supramaxilla 2 [ $^{*}$ ]. Small supramaxilla 2, lacking an antero-dorsal process extending on supramaxilla 1. Elongate maxilla with gently concave ventral margin $\left[{ }^{*}\right]$. Maxilla bearing row of conical teeth. Long lower jaw with lateral exposed portion of angular as long as half of jaw length. Oral margin of dentary platform-like, bearing numerous villiform teeth $\left[{ }^{*}\right]$. Quadrate with a well-developed antero-dorsal process [ $\left.{ }^{*}\right]$. Preopercle possessing a truncated ventral arm and a short dorsal limb ending below hyomandibular-opercular articulation $\left[{ }^{*}\right]$. Elongate, narrow interopercle extending below and medial to subopercle $\left[^{*}\right]$. Well-developed series of epineural, long epicentral $\left[{ }^{*}\right]$, and epipleural bones present. First uroneural reaching preural centrum 2. Five hypurals. Parhypural and hypurals 1 and 2 partially fused to each other [ $\left.{ }^{*}\right]$. Broad diastema between hypurals 2 and 3. Complete series of epaxial basal fulcra present. Few and elongate fringing fulcra associated with dorsal leading margin of caudal fin. Three 'urodermals' present. 
Etymology. Bavarichthys, referring to the rich fossiliferous region of Bavaria, from which the fish was recovered and -ichthys (Greek) for fish.

\section{Bavarichthys incognitus n. sp.}

Figures 3-12

Diagnosis. Same as generic diagnosis.

Etymology. The specific name incognitus is given in recognition of this first recorded incident of this fish in a region with more than two centuries of paleontological research.

Holotype. JME SOS 4934a and 4934b is preserved in part and counterpart. It is an almost complete specimen missing the distal tips of the paired fins and anal fin rays (Figs 4A, B). The intestine is partially preserved as well as the stomach content represented by remnants of Orthogonikleithrus hoelli (Figs 3A, B, 4A, B). The specimen was collected by the Höll family (Bitz, Bavaria), who sold it to the Friends of the Jura-Museum, and whose members donated it to the Jura-Museum Eichstätt to be studied.
Type locality and age. Ettling, Bavaria, Germany. Late Jurassic, probably Early Tithonian.

\section{Description}

The fish (Figs 4A, B) is elongate, with a moderately long head as deep as the body, with a terminal mouth, large jaws, especially a massive lower jaw. The holotype is about $164 \mathrm{~mm}$ in total length and $136 \mathrm{~mm}$ in standard length. The snout length, calculated as the distance between the anterior margin of the orbit and the anterior margin of the premaxilla is characteristically long, about $26 \%$ of the head length. Apparently, this value corresponds to the longest known snout among crossognathiforms, for which the quality of preservation allows comparisons. The head of Bavarichthys is about $30 \%$ in standard length, with eyes relatively small, their diameter about $19 \%$ in head length. The head is almost triangular in shape with its deepest points at the posterior end of the cranial roof. The caudal peduncle is moderately narrower than the rest of the body. The dorsal fin is positioned slightly posterior to the halflength of the fish, at about $60 \%$ of the standard length, whereas the pelvic fins are positioned slightly anteriorly (about $59 \%$ of the standard length). The cranial bones are free of ganoine and lack ornamentation.
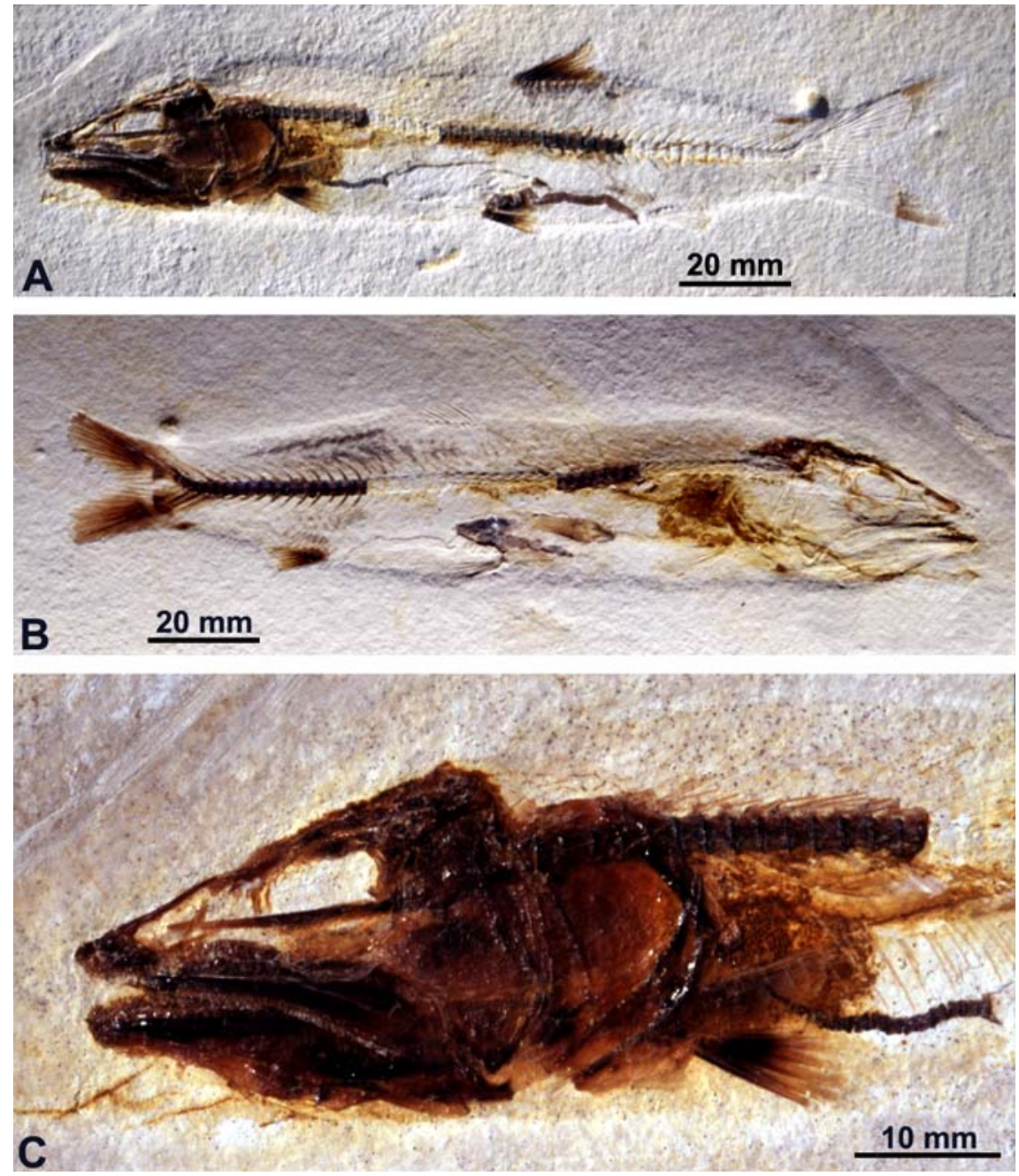

Figure 4. Bavarichthys incognitus n. gen. n. sp. in lateral view. A. Holotype JME SOS 4934a under white light. B. Holotype JME SOS 4934b under white light. C. Head in lateral view (JME SOS 4934a) under white light. The stomach content includes vertebrae of Orthogonikleithrus, which are found posterior to the pectoral girdles. 


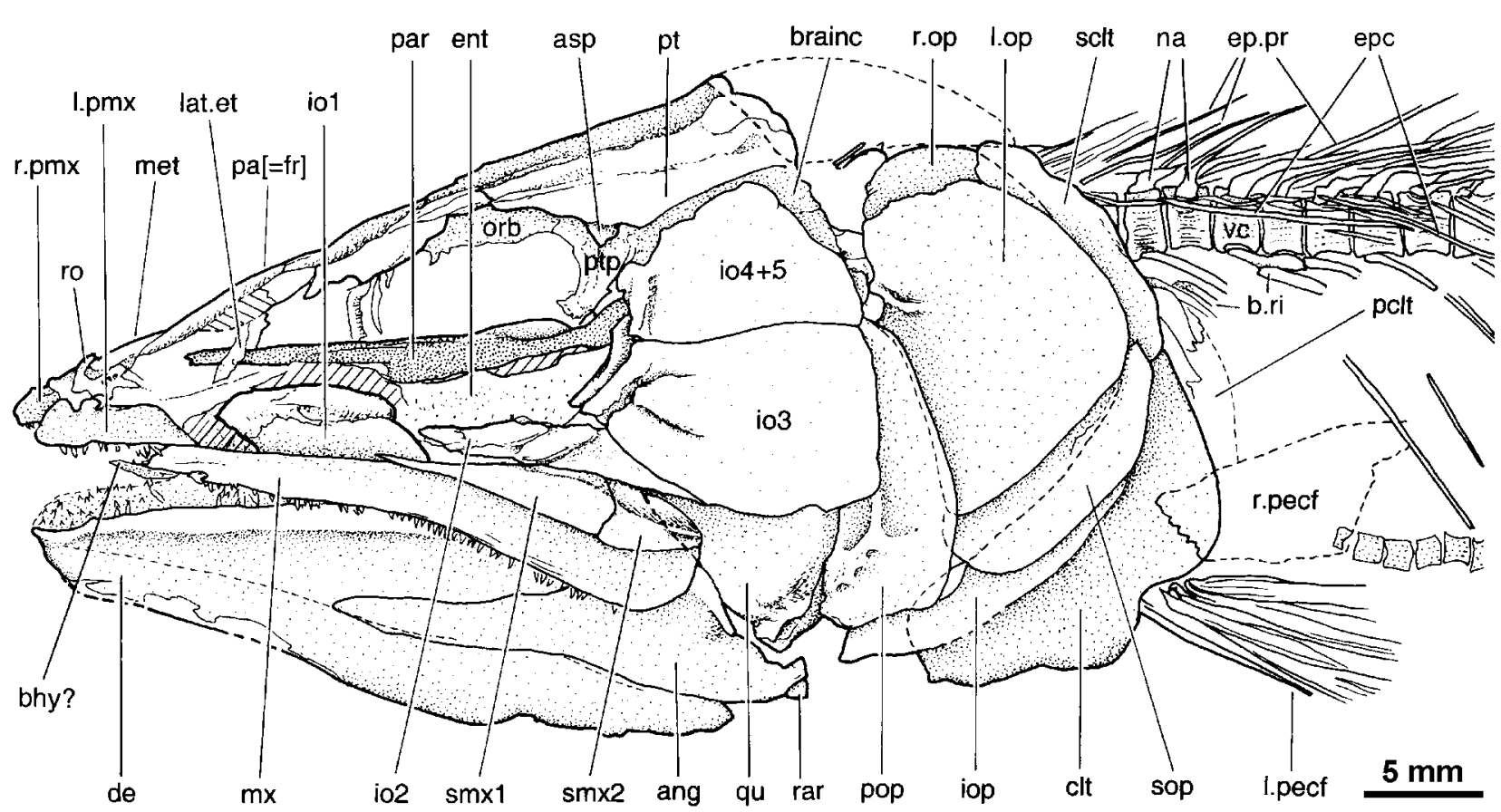

Figure 5. Bavarichthys incognitus n. gen. n. sp. Drawing of head and anterior part of the body in lateral view (JME SOS 4934a); the extrascapula (discontinuous line) is added from JME SOS 4934b. Abbreviations: ang - angular; asp - autosphenotic; brainc - braincase; bhy - basihyal?; clt - cleithrum; b.ri - broken ribs; de - dentary; ent - entopterygoid; epc - epicentral bones; ep.pr - epineural processes; io1-5 - infraorbitals 1-5; iop - interopercle; lat.et - lateral ethmoid; l.pmx - left premaxilla; l.op - left opercle; l.pecf - left pectoral fin; mx - maxilla; met - mesethmoid; na - neural arch; orb - orbistosphenoid; pa[= fr] parietal bone [= frontal bone of traditional terminology]; par - parasphenoid; pclt - postcleithrum; pop - preopercle; pt pterotic; ptp - pterosphenoid; qu - quadrate; rar - retroarticular; ro - rostral ossicle?; r.pmx - right premaxilla; r.op - right opercle; r.pecf - right pectoral fin; sclt - supracleithrum; smx1-2 - supramaxillae 1-2; sop - subopercle; vc - vertebral centra.

Braincase. It is very difficult to describe the braincase because it is partially covered by other bones or the bones, as shown by the skull roof, are partially sunk in the median region or are twisted. The main element of the skull roof (Fig. 5) is the parietal bone (= frontal bone of traditional terminology) but the bone is too fragmented as to allow a description. Anteriorly, the parietal bone sutures with an elongate mesethmoid that seems to be narrow and produces two short antero-lateral processes. In the snout, a displaced small bone lies on the mesethmoid. The shape of the bone resembles that of the rostral ossicles of elopiforms. The sutures between the parietal and postparietal and parietal and pterotic are not discernable, and apparently the small postparietals (= parietal bones of traditional terminology) are sutured medially. Lateral bones of the skull roof cover the supraoccipital. It is assumed here that the supraoccipital crest was very small because there is no evidence of it dorsal or dorso-posterior to the preserved skull roof bones. The postorbital region of the braincase is short, so that the pterotic forming the dorso-lateral region of the skull roof is also short. A large extrascapular bone is preserved in JME SOS 4934b (Figs 3B, 5, 6A) and its counterpart is observed in JME SOS 4934a. Because the extrascapulae seem to overlap each other it is not possible to determine the condition of the extrascapular canal. The exposed region of the autosphenotic is small, and slightly triangular, whereas its latero-ventral process forming part of the lateral wall of the braincase is heavily ossified and well developed.

Anteriorly, and below the parietal, the autosphenotic sutures with a small endochondral bone, the pterosphenoid (Fig. 5). Anterior to the latter is another endochondral bone, the orbitosphenoid, which extends anteriorly. The sutures between the autosphenotic and pterosphenoid and between the pterosphenoid and orbitosphenoid are unclear. Only remnants of the right and left lateral ethmoids are preserved and they do not add any significant information. Only a section of the parasphenoid is visible from the base of the braincase. It seems to be a broad bone but no description is allowed due to its incomplete preservation. Small teeth are scattered on the lateral sides of the parasphenoid, but it is more appropriate to interpret them as displaced teeth of the entopterygoid, because no teeth or sockets for teeth are observed on the parashenoid. It is unclear whether a basipterygoid process was present or not.

Apparently, the supraorbital and otic sensory canals are deeply enclosed in bone because most of their trajectories are not visible, with the exception of a short segment in the pterotic. A parietal branch of the supraorbital canal has not been observed in the parietal area nor in the preserved postparietal region. No pitlines are observed on the cranial bones. 
Circumorbital series. The dorsal part of the circumorbital ring is incompletely preserved. Infraorbital 1 (Fig. 5) is partially hidden by the dorsal margin of the maxilla so that its ventral margin is unknown. The infraorbital 1 was a large, slightly oval shaped bone with the infraorbital canal running near the middle region of the bone, but probably not reaching the anterior third of the bone.

Infraorbital 2 (Fig. 5) has a curious shape, with a narrow orbital region of thin bone that is projected postero-ventrally, ending in a sharp tip. The bone is broken at its postorbital corner. The infraorbital sensory canal is enclosed by thin bone and the canal is broad and no sensory tubule is observed. A slightly similar bone seems to be present in Goulmimichthys arambourgi according to the restoration by Cavin (2001, fig. 5).

The posterior orbital region is covered by two large bones that are interpreted here as infraorbitals 3 and $4+5$. Infraorbital 3 (Fig. 5) is the largest bone of the series and together with infraorbital $4+5$ extends onto the anterior region of the preopercle. A similar extension of the posterior infraorbital bones on the preopercle is present in the Late Jurassic varasichthys and chongichthyids (Arratia 2008a, figs 3A, 6A) and in some pachyrhizodontoids like Notelops and Rhacolepis (Forey 1977, figs 6, 20). In contrast, the posterior margin of the posterior infraorbitals $3-5$ broadly extending onto the preopercle and opercle is the condition found in crossognathids (e.g., Teller-Marshall \& Bardack 1978, fig. 8; Taverne 1989) and certain pachyrhizodontoids like Goulmimichthys (Cavin 2001, fig. 5), Michin (AlvaradoOrtega et al. 2008, fig. 2C), and Aquilopiscis (Cumbaa \& Murray 2008, fig. 7).

Infraorbital 3 (Fig. 5) is almost rectangular-shaped, with a slightly concave anterior margin, with dorsal and posterior margins almost straight, whereas the ventral one is slightly rounded. The infraorbital sensory canal, enclosed by bone, runs at the orbital margin of the bone, and apparently produces two short sensory tubules that do not reach the half-length of the infraorbital 3 .

The most dorsal bone of the series is interpreted as a result of [a phylogenetic] fusion of infraorbital bones 4 and 5 by comparison with the independent five infraorbital bones found in basal crossognathiforms as chongichthyids and varasichthyids (Arratia 2008, figs 3, 6) and in other basal teleosts (see below Discussion and final comments). The orbital margin of infraorbital $4+5$ (like the condition shown by infraorbital 3 ) is slightly curved and encloses the infraorbital sensory canal. The dorsal and posterior margins of the bone are broken so that the bone was slightly larger than it is shown in its current preservation. Apparently, the infraorbital canal lacks sensory tubules in this bone.

The dermosphenotic is not preserved, but according to the space left between the incomplete supraorbital bone, the autosphenotic, the pterotic and infraorbital $4+5$, the dermosphenotic may have been large.
A piece of an elongate bone, placed lateral to the orbital border of the parietal bone, is interpreted here as part of the supraorbital. If this interpretation is correct, then the supraorbital was a long and large bone extending close to the dorsal margin of infraorbital 1, extensively covering the lateral ethmoid region. There is no evidence of an independent antorbital bone. There are remnants of the anterior and posterior sclerotic bones.

Upper jaw. The upper jaw (Figs 4C, 5) is slender and long, reaching behind the orbit, and covering laterally the anterior region of the quadrate. It is composed of premaxilla, maxilla and two supramaxillary bones.

The premaxilla (Figs 4C, 5) is small, with a very short ascendent process. Eleven small conical teeth are preserved at the external row, but more teeth may be present. No large teeth are observed, not even with ultraviolet light techniques.

The maxilla (Figs 4C, 5) is long, but shorter than the lower jaw, a condition shared with the Late Jurassic Chongichthys (see Arratia 1982, 1986) and Cretaceous crossognathiforms (see Taverne 1989; Forey 1977; Maisey 1991a, 1991b; Cavin 2001, Blanco \& Cavin 2003; Cumbaa \& Murray 2008). The maxillary blade is shallow and its depth increases slightly posteriorly. The bone is not straight as in crossognathids and pachyrhizodontoids, but it is gently concave at mid-length, and its posterior tip is rounded. The maxilla is incompletely preserved rostrad so that the anterior tip of the articulatory region is missing. However, considering the surrounding bones it is possible that the articular process of the maxilla is short. A single row of relatively small conical teeth is present. The teeth increase in sizes slightly at the posterior half of the bone. Their bases are unfused to the bone as demonstrated by the presence of scattered teeth lying below the oral margin of the maxilla.

Two supramaxillary bones (Fig. 5) cover the posterodorsal margin of the maxilla. Both bones together occupy over the half of the length of the maxillary blade. Supramaxilla 2 is small, broad and lacks an antero-dorsal process overlapping the posterior tip of supramaxilla 1. Supramaxilla 1 is a long, triangular bone that extends forward reaching below the anterior margin of the orbit. The supramaxillae contact one another in a sigmoid-shaped suture.

Lower jaw. The broad and massive lower jaw (Figs 4C, 5 ) is composed laterally by three bones: the dentary, angular, and retroarticular. The oral margin of the jaw does not project in a high coronoid process, but it ascends gently posteriorly (Fig. 6A). The posterior part of the jaw is slightly projected caudad to the quadratemandibular articulation, in a short process that is truncated posteriorly.

The dentary (Figs 4C, 5, 6A) contributes to most of the lower jaw length, extending below the angular ventro-posteriorly. The dentary has a broad platform-like oral margin covered with many relatively small conical, 

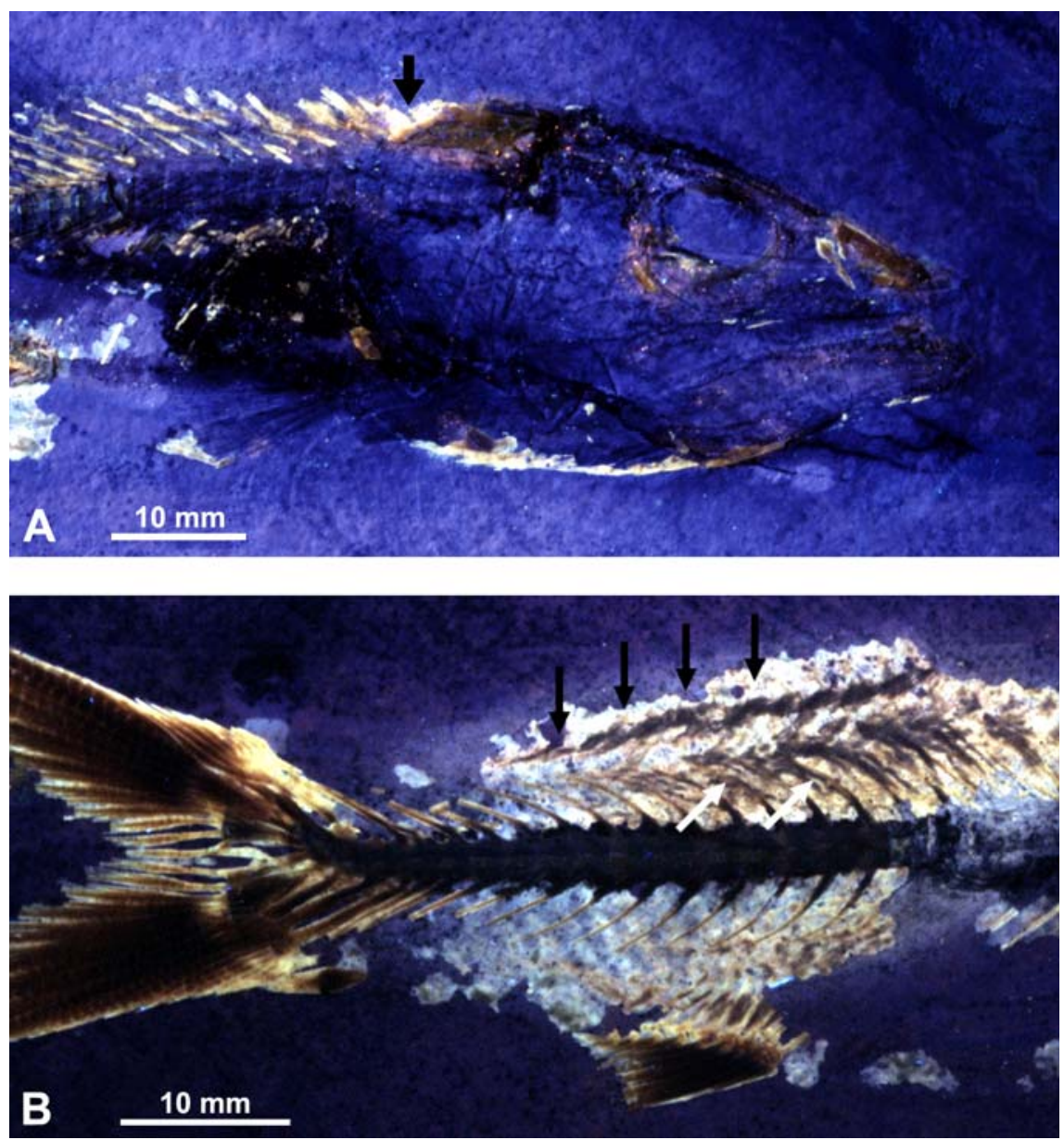

Figure 6. Bavarichthys incognitus n. gen. n. sp. A. Head and anterior part of the body in lateral view (JME SOS 4934b) under ultraviolet light. Thick arrow points to the first supraneural. B. Posterior part of body illustrating the vertebral column, epaxial intermuscular bones and anal fin. Black arrows point to an extra series of thin intermuscular bones, whereas white arrows point to epineural processes.

villiform teeth, irregularly arranged. In contrast, one row of conical dentary teeth is the common feature found in other crossognathiforms.

The lateral portion of the angular extends anteriorly, occupying almost the half-length of the mandible. In contrast, a short angular is the common condition observed on the lateral face of the jaw of other crossognathiforms. It is unclear whether the angular and articular bones are fused medially.

A small section of the retroarticular (Fig. 5) is observed at the ventro-posterior corner of the jaw. It is unclear, due to condition of preservation, if the retroarticular is medially fused to the angular and articular bones or not.

The mandibular sensory canal is enclosed by bone and runs closer to the ventral margin of the dentary than to the oral margin, with the exception of the anterior part where the canal gets closer to the oral margin. The orientation of the canal in the angular is unclear, but a posterior opening of the mandibular canal is not present on the lateral side of the angular, so that we interpret it that the opening is medially or posteriorly placed.

Palatoquadrate and suspensorium. Most bones of the palatoquadrate and suspensorium are hidden by other bones so that the description is restricted to few elements that are exposed such as the entopterygoid and quadrate.
The thinly ossified entopterygoid (Fig. 5) is partially preserved between the parasphenoid and the infraorbital bones 2 and 3 . Numerous irregularly placed small conical teeth are present on the oral face of the entopterygoid. Additionally, there are small conical teeth scattered along the oral surface of the buccopharyngeal cavity that make their association with particular bones difficult. (The teeth are easily identified because their acrodin tips are black.) Because of their position, they could be dermopalatine and/or ectopterygoid teeth.

The quadrate (Fig. 5) is slightly triangular-shaped, with its antero-dorsal corner projected in a well-developed process that has not been described or illustrated in other crossognathiforms. The postero-ventral process of the quadrate as well as the symplectic are covered by the preopercle and most of the dorsal margin of the quadrate is covered by the ventral margin of infraorbital 3. The articulatory condyle of the quadrate is small in proportion to the size of the bone and to the size of the lower jaw. The quadrate-mandibular articulation (Figs 4C, 5) is placed far caudad of the posterior margin of the orbit.

The posterior infraorbital bones are covering the hyomandibula laterally. However, it is possible to observe the outline of the hyomandibula through the thin infraorbitals. The strong opercular process of the hyomandibula is observed between the posterior margin of the 
infraorbital $4+5$ and the anterior margin of the opercle. The hyomandibula is inclined antero-dorsally with respect to the skull roof bones in a position more similar to that shown by Michin (Alvarado-Ortega et al. 2008) than to the vertical position described for pachyrhizodontoids by Forey (1977).

Opercular, branchiostegal series, and gular plate. The position of the whole opercular apparatus is interesting to be noted because the opercular bones (Figs 4C, 5) are placed posterior or almost posterior to the posterior margin of pterotic.

The preopercle (Fig. 5) is almost triangular in shape, with a truncated ventral arm and a moderately short dorsal limb that ends just below the level of the articulation between hyomandibula and opercle, almost in front of the dorsal margin of infraorbital bone 3. A significant portion of the anterior region of the preopercle is covered by the posterior part of infraorbital 3. The posterior margin is gently curved, whereas the ventral margin is slightly notched. Only the ventral pathway of the preopercular sensory canal is visible, running close to the anterior margin of the bone. The preopercular sensory canal (Fig. 5) is bone enclosed and produces three short branches or tubules at the middle-ventral region of the bone, a condition similar to that found in chongichthyids and pachyrhizodontoids among crossognathiforms.

The dorsal part of the right opercle is preserved, while the same region of the left opercle is damaged, but using a combination of information provided by both bones it is possible to have an accurate description of this bone. The opercle (Fig. 5) is large and dorsally is medially curved, but its dorsal margin is broadly separated from the skull roof bones and the braincase. The anterior margin of the opercle is notched at the level of the articulatory facet for the hyomandibula and continues ventrally in a gently curvature. The ventral margin of the opercle is oblique. The external surface of the bone is smooth, with the exception of a gentle crest at the level of the articulation with the hyomandibula.
The subopercle (Fig. 5) is a moderately narrow bone. Its depth is about 4.6 times in the opercular depth. Its ventral margin is gently rounded and is in continuation with the rounded postero-ventral corner of the opercle. The antero-dorsal process is short and sharp.

The bone interpreted here as the interopercle (Fig. 5) is unusual because it is relatively broader and longer than that in other teleosts, extending posteriorly below and medial to the subopercle. The shape and size of the bone do not qualify it as to be interpreted as the last branchiostegal ray.

The posterior margins of the opercle and subopercle, with the ventral margin of the interopercle, form a gently rounded profile of the opercular apparatus.

There are fragments of 10 branchiostegal rays, which seem to be narrow and slightly elongate and probably correspond to the most anterior ones of the series.

There is no evidence of a gular plate.

Vertebral column and intermuscular bones. There are 53 or 54 vertebrae (including the ural centra), 18 or 19 of which are caudals, so that the abdominal region (Fig. 4A, B) is much longer than the caudal region. The first five or six vertebrae (Figs 4C, 5) are laterally covered by the opercle.

All vertebrae are well ossified. Numerous fine longitudinal crests and grooves (Figs 5, 7) ornament the lateral surfaces of the abdominal centra. The crests and grooves disappear in the caudal centra being replaced by one lateral longitudinal crest, which is more conspicuous caudally. The neural arches of the abdominal vertebrae are autogenous and the halves of each neural arch are unfused medially. The neural arches are comparatively narrow and they sit in the middle-dorsal region of the centrum. Most of the neural spines of the abdominal region are strongly inclined toward the axis of the body, and they are short, shorter than their epineural processes (sensu Arratia 1999). The parapophyses (Fig. 7) are fused to the ventro-lateral region of each centrum and are represented by a broad bony edge partially surrounding a cavity that is ventro-posteriorly oriented and where the rib articulates.

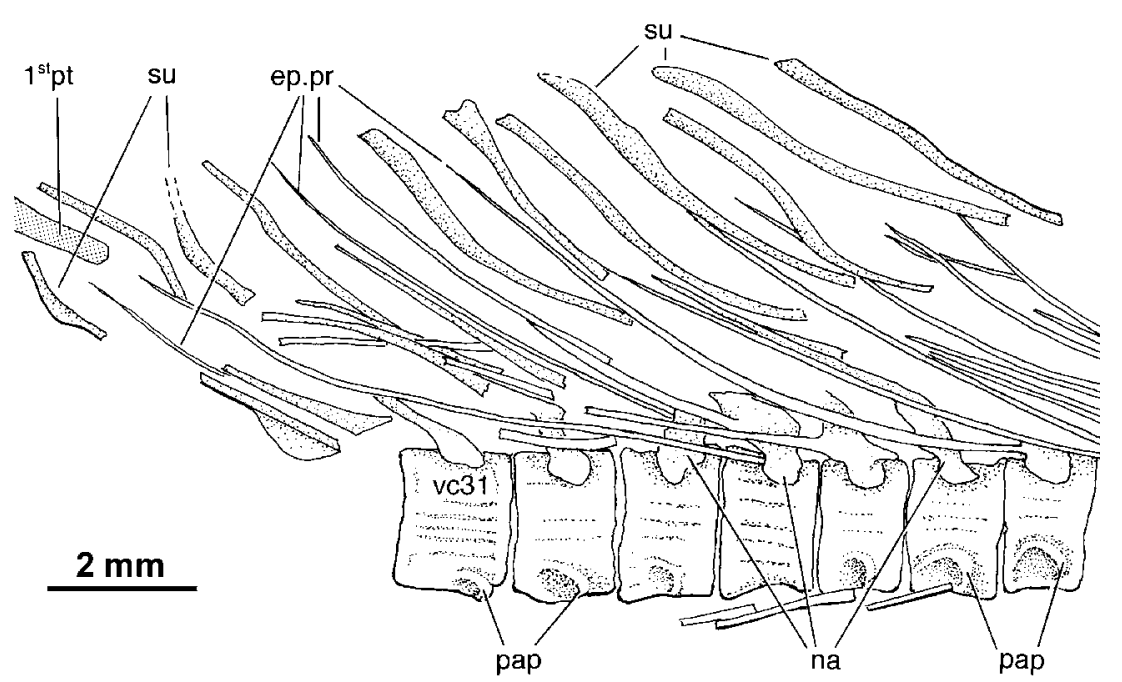

Figure 7. Bavarichthys incognitus $\mathrm{n}$. gen. n. sp. Abdominal vertebrae close to the dorsal fin origin and associated bones. Abreviations: ep.pr - epineural processes; na - neural arches; pap - parapophyses; su - supraneural bones; vc31 probably vertebral centrum $31 ; \mathbf{1}$ st pt first dorsal pterygiophore. 


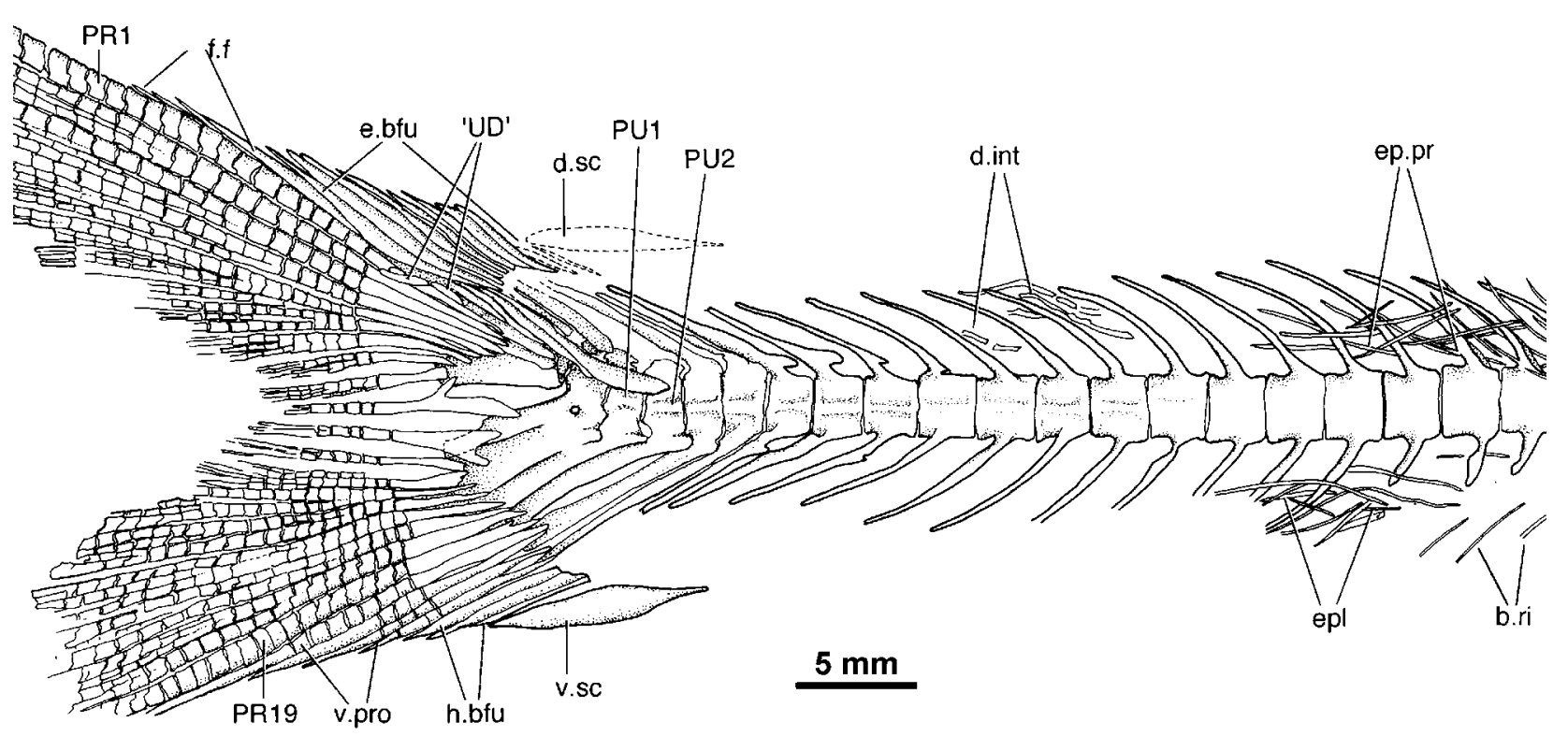

Figure 8. Bavarichthys incognitus n. gen. n. sp. Caudal vertebrae and caudal fin in lateral view (JME SOS 4934b). Abbreviations: b.ri - broken ribs; d.sc - dorsal caudal scute; d.int - dorsal intermuscular bones; e.bfu - epaxial basal fulcra; epl - epipleural bones; ep.pr - epineural processes; f.f - fringing fulcra; h.bfu - hypaxial basal fulcra; PR1, 19 - principal rays 1 and 19; PU1-2 - preural centra 1 and 2; 'UD' - 'urodermals'; v.pro - ventral precurrent or procurrent rays; v.sc - ventral caudal scute.

Most midcaudal vertebrae (Fig. 8) have centra as deep as long with fused dorsal and haemal arches. Both the dorsal and haemal arches are placed at the mid region of the centrum. The neural and haemal spines are narrow and each ends in a sharp tip. They are moderately inclined toward the body axis. The inclination of the spines is more pronounced caudally.

Although the anterior ribs are almost straight, the ribs (Figs 3A, B) closer to the level of the dorsal fin and below it are strongly inclined postero-ventrally almost reaching the ventral margin of the body. They seem to be thin but well ossified.

The supraneural bones are hardly observed under white light, but they are visible under ultraviolet light (compare Figs $3 \mathrm{~A}$ and $\mathrm{B}$ and $4 \mathrm{~B}$ and $6 \mathrm{~A}$ ). A complete series of supraneurals (Fig. 3C) extends between the posterior part of the cranium and the beginning of the dorsal fin. One small sigmoid-shaped supraneural (Figs 3C, 7) lies between the first and second dorsal pterygiophores. The anteriormost two supraneurals are large, broad bones, especially the first one (Fig. 6A). The following two supraneurals are also broad, but more slender than the first two. The following supraneurals are slender and sigmoidal-shaped. In general, the supraneural bones are poorly known in crossognathiforms, with the exception of Chongichthys (Arratia 1982), so that comparisons are not possible at the moment.

The series of very long epineural processes (Figs 3C, $6 \mathrm{~B}, 7)$ of the neural arches extend along the abdominal region ending just posterior to the dorsal fin base. Posterior to the series of epineural processes, free, elongated, thin epineural bones lie laterally to the neural spines, in the epaxial body musculature of the caudal region. In addition, the fish shows - under ultraviolet light - an unusual additional series of thin elongate bones (Fig. 6B) that extend dorsal to the epineural series in the epaxial musculature of the caudal region. These small thin bones may correspond to the elements named "myorhabdoi" by Patterson \& Johnson (1995).

A series of bony epicentrals (sensu Patterson \& Johnson 1995; Figs 3B, 4C, 5 herein) lies on the lateral surfaces of the abdominal centra and extend over the ribs. They are long, thin bones that may extend over five or more centra and they are inclined postero-ventrally.

A series of thin, delicate epipleural bones lies laterally to the last ribs and to the first haemal spines, in the hypaxial musculature. The short epipleurals are followed by numerous thin and elongate bones (Fig. 8). It is unclear how far caudad the dorsal and ventral intermuscular bones reach in the caudal region.

Paired fins. The pectoral girdle and fins (Figs 4A, C, 5) are difficult to describe because of conditions of preservation. The pectoral fin (Fig. 4C) is positioned low in the flank, close to the ventral margin of the body as in other crossognathiforms. A long, narrow supracleithrum, a massive cleithrum, and a well-developed postcleithrum are preserved. The bases of about six pectoral rays are preserved.

The pelvic girdle and fins are also poorly preserved. One pelvic bone or basipterygium lies partially over the other making their description difficult. The basipterygia (Fig. 9) are elongated and slightly triangular in shape with the narrow articular region for the pelvic rays (and for radials if present) oriented posteriorly. The lateral margin of each basipterygium is heavily os- 


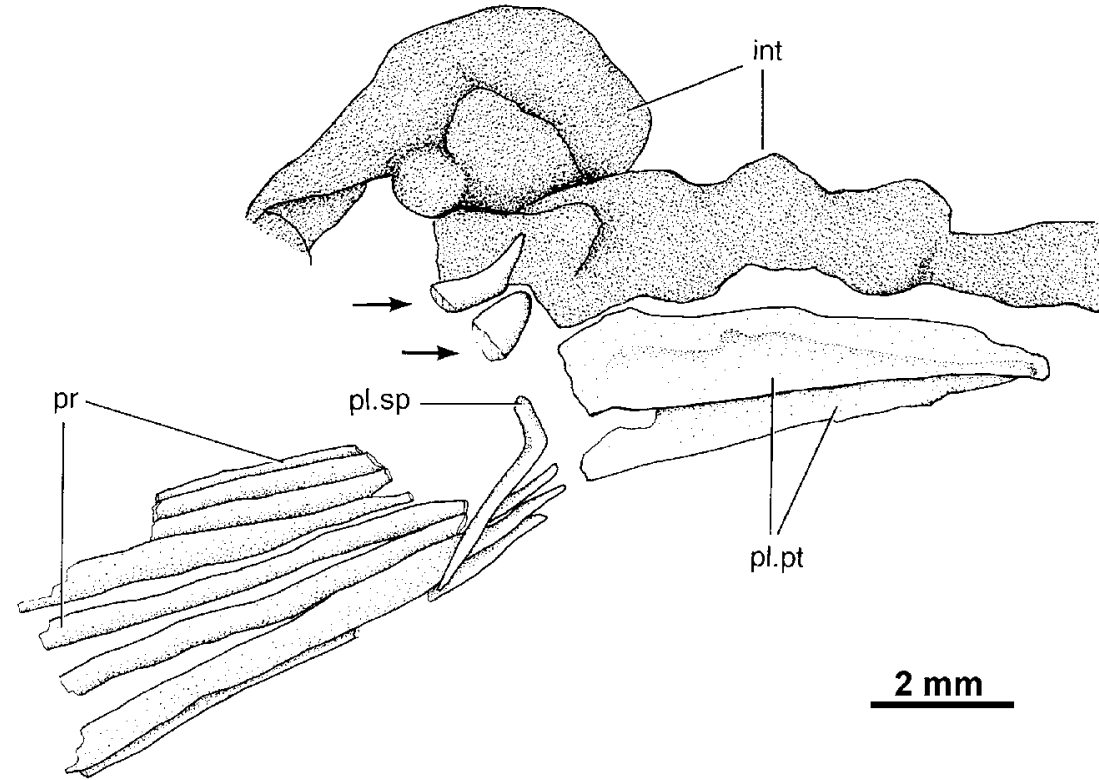

Figure 9. Bavarichthys incognitus $\mathrm{n}$. gen. n. sp. Pelvic girdle and its associated elements and foldings of the intestine (int) (JM-E SOS 4934b). Abbreviations: pl.pt - pelvic plates or basipterygia; pr pelvic rays; pl.sp - pelvic splint. sified. A well-ossified pelvic splint (Fig. 9) and remnants of approximately seven rays, with long, broad bases are present.

Dorsal and anal fins. The dorsal fin (Fig. 10) is acuminated, with long anterior and very short posterior principal rays producing a deep concave dorsal margin of the fin. (For terminology of the fin rays see Arratia 2008b). The dorsal fin has five anterior precurrent (or procurrent) rays that are unsegmented and unbranched. The first two are very short and the fifth is the longest, but still it is about the half of the length of the first principal ray. There are 12 principal rays including the first segmented-but-unbranched ray and 11 branchedand-segmented rays. The principal rays have long bases and they are segmented and branched distally.

The dorsal fin has 14 dorsal pterygiophores preserved. The first one is almost lanceolate with a very short antero-ventral process that is joined to the main body of the bone by a thin bony lamella as revealed by the observation under ultraviolet light (compare Figs $3 \mathrm{~A}$ and $3 \mathrm{~B}, \mathrm{C})$. The first six pterygiophores are broad, but the posterior ones are incompletely preserved. The bases of the pterygiophores (at least the 6th and last ones) are elongate. It is reasonable to assume that the elongation is due to the presence of middle and distal radials whose articulations are not visible due to conditions of preservation. The last pterygiophore, a slightly triangular bone, is the smallest of the series.

The short anal fin (Fig. 4B) is placed posteriorly to the dorsal fin and it is closer to the caudal fin than to the pelvic fin. It consists of three short precurrent (or procurrent) rays and 9 principal rays. The distal tips of the principal rays are broken. Only the first pterygiophores are partially preserved.

Caudal fin and endoskeleton. Although some of the distal tips of the caudal fin rays are broken, the tail is almost completely preserved when both part and counterpart of the holotype are set together. The caudal fin (Figs 4A, B, 6, 8) is deeply forked, with very short middle principal rays - which are completely preserved - in comparison to the long leading marginal principal rays.

Five strongly ossified preural vertebrae (Fig. 8) support the caudal fin rays. A pronounced lateral crest extends along preural centra 5 to 2 , but the crest is more

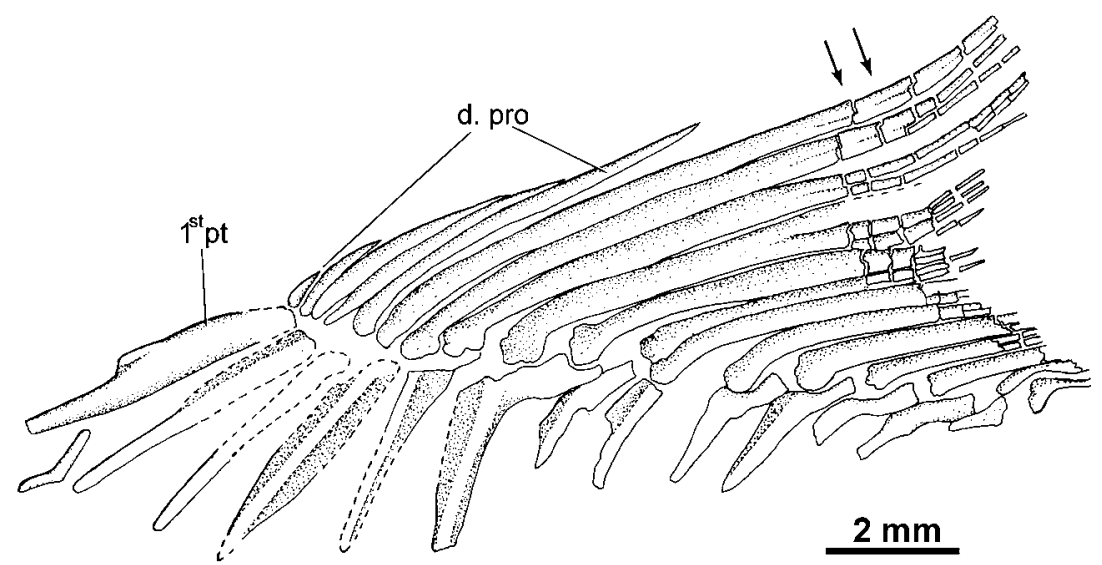

Figure 10. Bavarichthys incognitus n. gen. n. sp. Restoration of dorsal fin based on part and counterpart of JME SOS 4934. Arrows points to the first principal ray. Abbreviations: d.pro - dorsal precurrent or procurrent rays; 1 st pt - first dorsal pterygiophore. 


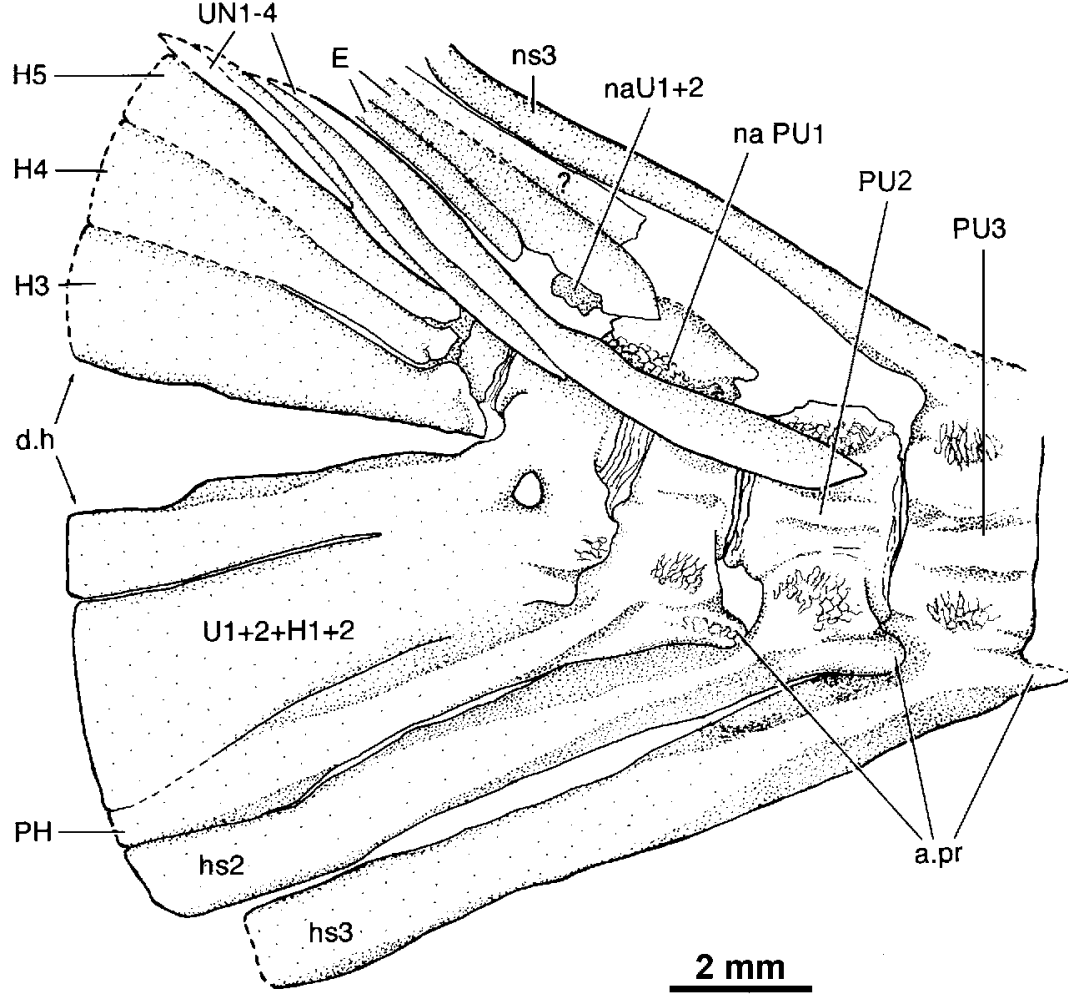

Figure 11. Bavarichthys incognitus n. gen. n. sp. Caudal skeleton without rays (JME SOS 4934b). Abbreviations: a.pr - anterior processes; E - epurals; H1-5 - hypurals $1-5$; hs2-3 - haemal spine of preural centra 2-3; d.h - hypural diastema; naPU1 - neural arch of preural centrum 1; naU1 + 2 - neural arch of ural centra $1-2$; ns3 - neural spine of preural centrum 3; PH - parhypural; PU1, 2, 3 - preural centra 1,$3 ; \mathbf{U 1}+\mathbf{2}+\mathbf{H} \mathbf{1}+\mathbf{2}-$ ural centrum $1+2$ plus hypurals $1+2$; UN1-4 - uroneurals 1-4.; ? - unclear due to preservation; it could be part of a epural or a spine. gently on the lateral surface of preural centrum 1 and it is absent on the ural centra. Both neural and haemal arches of preural centra 5 to 3 are massive and fused to their respective centrum; they likely retain cartilage surrounded by bone because of the spongy aspect. The neural spines of preural vertebrae 5 to 3 are long and narrow being neural spine 3 the longest. The broad neural arch of preural centrum 2 (Fig. 11) is broken dorsally and it is unclear if the incomplete spine dorsal to this centrum is a long neural spine or is part of an epural. The haemal spine of preural centrum 5 is shorter than the spines of the following preural centra and bears a short anterior process at the base of the spine. The haemal spines of the following centra are long and progressively broader being the haemal spine of preural 1 the longest. The anterior processes located at both the arch and base of the haemal spines are well developed in preural vertebrae $3-1$.

A complete and broad neural arch (Fig. 11) is present on preural centrum 1 . The arch bears rudiments of the neural spine. Remnant of a neural arch is above the first ural centrum (or ural centrum $1+2$ of the polyural terminology). The haemal arch of preural centrum 1 is fused with its centrum. The haemal arch bears a short and massive anterior process, and a hypurapophysis is missing on the lateral view of the arch. The parhypural is partially fused to hypural 1 . This interpretation is based on incomplete lines of fusion between both bones. (Partial fusions between the parhypural and hypural 1 and between hypurals are uncommon conditions in teleosts; however, these fusions are also observed in some ostariophysans such as certain cobitoids and trichomycterid catfishes; Arratia, pers. obser.).
Three ural centra (of the polyural terminology) bear five hypurals. The first ural centrum (Fig. 11) that it is interpreted as result of the fusion of ural centra 1 and 2 is strongly ossified and completely fused with the bases of hypurals 1 and 2 . There is a strong and broad articulation between preural centrum 1 and the first ural centrum. The independent and small second ural centrum (or ural centrum 3 of the polyural terminology) articulates with hypurals 3, 4 and 5 .

There are four independent uroneurals, which are inclined in a similar angle, one after the other. The first uroneural (Fig. 11) extends anteriorly reaching the dorso-lateral side of preural centrum 2, whereas the second uroneural reaches anteriorly the dorso-lateral side of the first ural centrum. The first uroneural is the largest of the series and slightly expanded antero-laterally. The second uroneural is long and narrower than the first one. The last two uroneurals (3 and 4) are small and fusiform-shaped. Two long epurals are preserved. It is unclear if a third epural could have been present or not.

Five hypurals (Fig. 11) are present. Since hypural 5 is long, large, and laterally covered by uroneurals 3 and 4 , there is no space for a sixth hypural. Hypural 1 is the largest and longest of the series. Hypural 2 is narrower than hypural 1 and as long as hypurals 1 and 3 . The bases of hypurals 1 and 2 and of parhypural are fused with each other and also with the first ural centrum. A joint between hypurals 1 and 2 is only visible distally. Hypural 3 is the broader element among the dorsal hypurals, whereas hypural 4 seems to be narrower than hypurals 3 and 5. A broad diastema is left between hypurals 2 and 3 , and this space is partially covered by the expanded bases of the middle principal rays. 
There are 10 epaxial basal fulcra, one long epaxial fringing fulcrum followed by three thin and elongate epaxial fringing fulcra, 19 principal rays, four hypaxial precurrent (or procurrent) rays, and three elements interpreted as hypaxial basal fulcra (Fig. 8). One long and narrow dorsal scute and a ventral scute precede the dorsal and ventral series of basal fulcra.

The two anteriormost elements interpreted as epaxial basal fulcra (Fig. 8) are preserved as imprint. They are followed by long, leaf-like elements that expand laterally partially covering the next fulcrum. It is not possible to confirm if the elements are paired or not. They are interpreted here as epaxial basal fulcra and not as precurrent or procurrent rays - because of their shapes, relationship to each other and because any of them is segmented (Arratia 2008b, 2009). The four fringing fulcra lie on the dorsal margin of the first principal ray. The base of the posteriormost epaxial basal fulcrum and the first principal ray produce an angle as described for other fishes by Arratia (2008b).

There are 10 principal rays (Fig. 8) associated with hypurals $3-5$, so that hypural 5 supports the first principal ray, and hypurals 3 and 4 support the other nine segmented-and-branched rays. There are 9 principal rays (Fig. 8) associated to hypurals 1 and 2, parhypural and haemal spine of preural centrum 2. The articulation between segments of the leading rays is mainly steplike or Z-shaped, but the articulations between segments are mainly straight in inner principal rays. The middle principal rays partially covering laterally the hypural diastema have expanded bases that are partially broken in the studied specimen. Probably others of the middle rays have expanded bases too, but their proximal regions are not preserved. Dorsal processes associated to the middle principal rays are absent.

Two long oval 'urodermals' (sensu Arratia \& Schultze 1992) and a small oval one (Fig. 8) lie on the base of the first principal ray. The 'urodermals' are very thin bones. 'Urodermals' are known in varasichthyids (e.g., Arratia 1981, 1991) and Bavarichthys n. gen. n. sp. among crossognathiforms.

Scales. Remains of scales are visible with ultraviolet light. The cycloid scales seem to be very thin.

\section{Phylogenetic analyses}

A phylogenetic analysis was performed to study the phylogenetic position of Bavarichthys n. gen. n. sp. among basal teleosts. The analysis is based on the coding of 193 unordered and unweighted characters (see Table 1 and Appendix for coding of characters and list of characters) and 53 taxa. The trees are rooted using user-specified outgroup methods. There is no difference in the topology of the ingroup when using different outgroup methods, but differences in number of trees and evolutionary steps.
Figure 12 shows the strict consensus of 15 equally most parsimonious trees at 682 evolutionary steps. The consistency index (CI) is 0.3842 and the CI excluding uninformative characters is 0.3824 . It is not a goal of this paper to discuss the phylogenetic relationships among teleosts, but rather to determine the position of Bavarichthys n. gen. Consequently, only the nodes at the base of the crossognathiforms will be presented and discussed below. The topology of the consensus between nodes $A$ and $G$ is identical to that in Arratia (2008a, fig. 7, nodes A-G).

Node D corresponds to the trichotomy including $A s$ calabos, the crossognathiforms, and all other teleosts. Node D1 represents the Crossognathiformes that comprises two clades. This node is supported by two uniquely derived characters 177[1]: large, roofed posttemporal fossa framed by the epiotic, pterotic, exoccipital, and intercalar present; and 178[1]: large, well developed extrascapular bone present) and four highly homoplastic characters (10[1]: parasphenoid toothless; 46[1]: retroarticular excluded from the joint facet for quadrate; 54[1]: gular plate absent; and 93[1]: acuminate dorsal fin present.

Node D2 stands at the branching of the Jurassic varasichthyids and is supported by 14 characters. Two of them are interpreted as uniquely derived (64[1]: preopercular sensory canal with many tubules in ventral limb reaching ventral and ventro-posterior margin of the preopercle; 143[1]: cycloid scales posterior to the pectoral girdle with circuli crossed by transverse lines in the middle field) whereas the other 12 are homoplastic $10[1], 46[1], 63[1], 84[1], 86[1], 89[1], 90[1], 113[1]$, 132[1], 133[1], 144[1] and 155[1]).

Node D3 stands at the branching of chongichthyids plus Bavarichthys n. gen. n. sp., pachyrhizodontoids, and crossognathids. This clade, that was left unnamed by Arratia (2008a), is supported in this study by four homoplasies (45[0], 49[0], 113[3], 182[1]). Node D4 stands at the branching of Bavarichthys plus pachyrhizodontoids and crossognathids. This branching is supported by eight homoplasies (29[1], 32[1], 105[1], 117[1], 120[2], 130[1], 181[1] and 185[1].

The consensus tree shows a resolved topology concerning the positions of the ichthyodectiforms, elopomorphs, osteoglossomorphs, the sister-group relationship clupeomorphs + ostariophysans and euteleosts (see Fig. 12: Nodes E-J). The topology of the euteleosts is identical to that in Arratia (1997, fig. 100, 1999, figs 19, 20). In contrast, the euteleostean clade $([$ Humbertia $+[$ Erichalcis $+[$ Leptolepides + Orthogonikleithrus]]]) appears at the base of the clupeocephalans in Arratia (2008a).

The 15 parsimonious trees differ in (1) the position of Ascalabos in relation to the crossognathiforms and more advanced teleosts, (2) in the unresolved relationships among varasichthyids, and (3) in the unresolved relationships among outgroup taxa. A hypothetical outgroup was used in a second analysis to test the results of the first analysis. Only 6 trees were obtained, and 


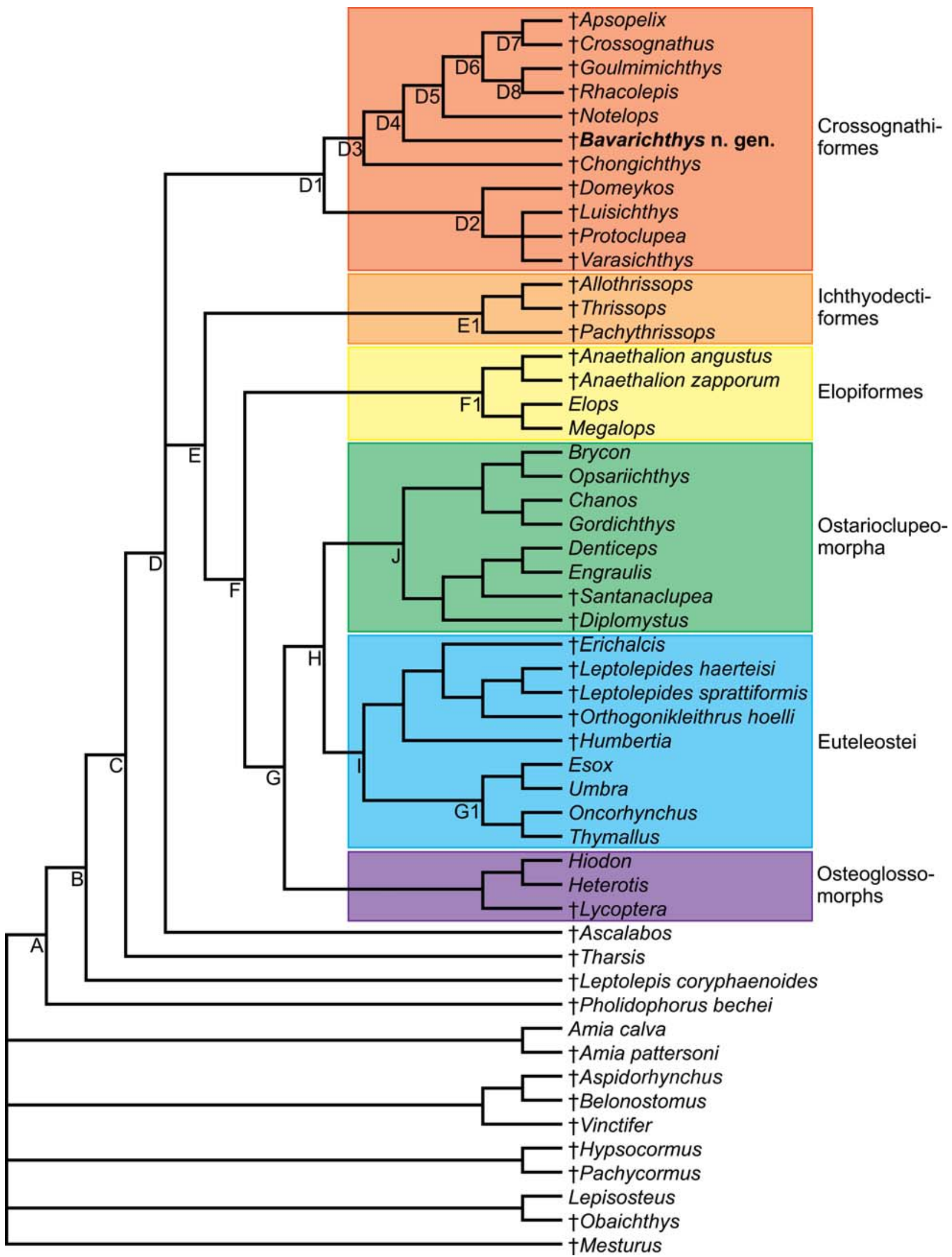

Figure 12. Hypothesis of phylogenetic relationships of some fossil $(\dagger)$ and recent teleosts. Consensus tree of 15 most parsimonious trees at 681 evolutionary steps (for characters and their coding see Table 1 and Appendix). 
Table 1. Data matrix representing 193 morphological characters belonging to fossil and extant teleosts. For a list of characters and character states see Appendix. A copy of the MacClade file can be obtained from GA.

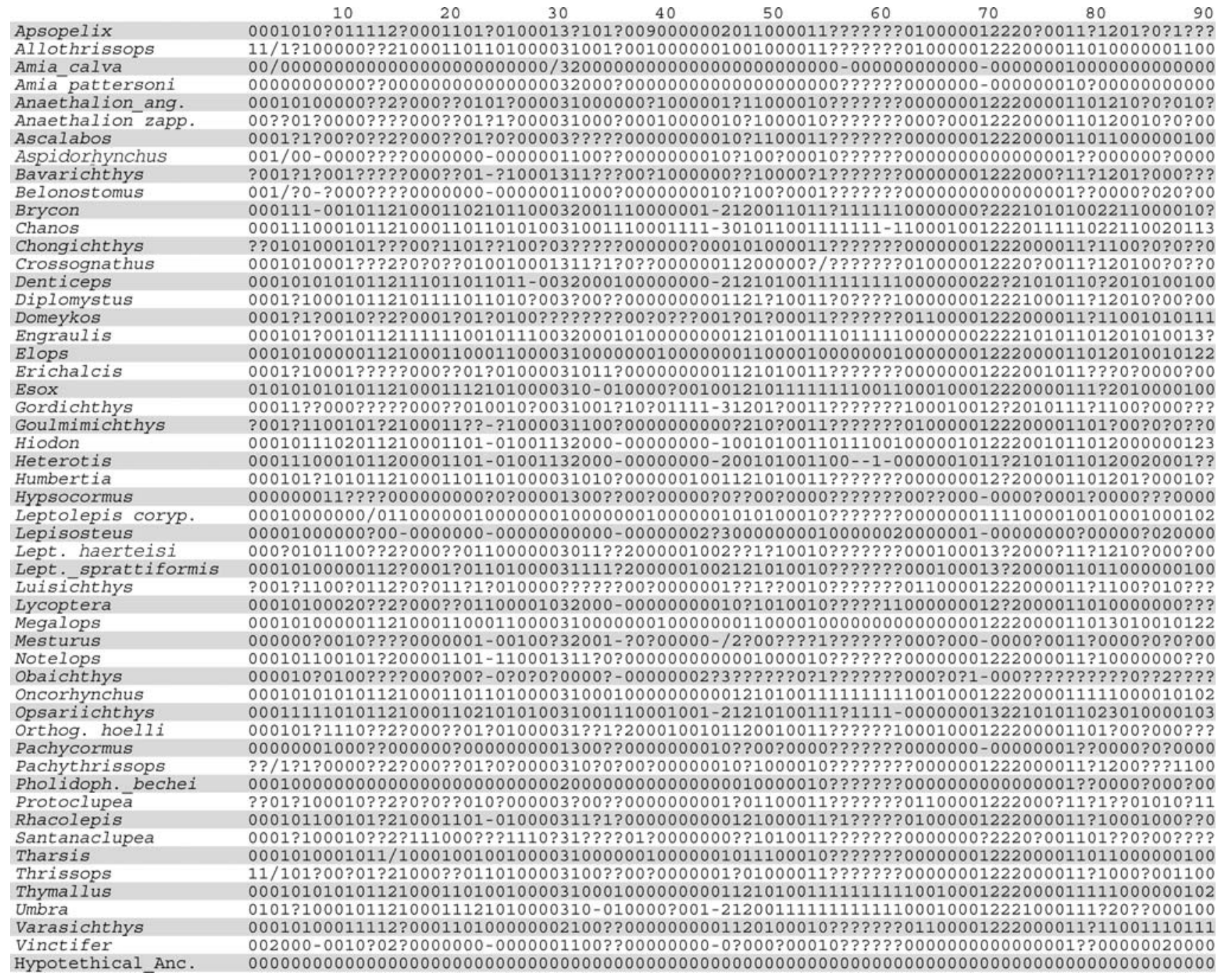

the consensus shows an identical topology to that in Figure 12 for the ingroup (Nodes A-J). The differences are in the relationships among the outgroup taxa.

\section{Discussion and final comments}

According to the results of the phylogenetic analyses, Bavarichthys incognitus n. gen. n. sp. from the Upper Jurassic of Germany is a basal crossognathiform, placed just above Chongichthys from the Oxfordian of Chile (see Fig. 12: Node D4). Additionally, the results of the phylogenetic analyses show that the monophyly of the crossognathiforms is weakly supported by four highly homoplastic characters.

The parsimony analysis gives some curious interpretations of some characters. For instance, the presence of a large, well-developed extracapular bone and a large, roofed posttemporal fossa framed by the epiotic, pterotic, exoccipital, and intercalar are interpreted as acquired independently in the two main lineages of crossognathiforms. In contrast, these characters were previously interpreted as synapomorphies of the pachyrhizodontiforms by Forey (1977), and more recently as synapomorphies of the Crossognathiformes (Taverne 1989, Arratia 2008a). Characters 10 (toothless parasphenoid present) and 46 (retroarticular excluded from the joint facet for quadrate) are also interpreted by the parsimony analysis as supporting both the crossognathiforms and the varasichthyids. It is obvious that with the current information on crossognathiforms we are unable to solve the problem of interpretation of these characters, but these results are important because they point to the need to re-evaluate the inclusion of varasichthyids within the crossognathiforms when more material is available.

The present study reveals that some characters previously hypothesized to support the pachyrhizodontoids, crosssognathids, and crossognathiforms need further study. The addition of the basal crossognathiform $\mathrm{Ba}$ varichthys n. gen. changes the distribution of certain characters. For instance, the parsimony analysis assumes that the presence of the fusion of infraorbital 4 and 5 is a synapomorphy of Bavarichthys plus more advanced members at Node D4 (Fig. 12). However, this 
Table 1. (continued)

100

110

120

130

140

150

160

170

180

190

0110011000000010100 ?/0200110020000001?111120110010010??0?00?1100???21??211?1??100000001111?1000??000001 $10110220000100 / 000001011011000010000 / 2101120010000010000 ? 00 ? 1100211111121111 ? ? 100000000011000010 ? 000001$ $00000000000110000100100-0000000000002101--0101011000000100000111000-000000000000000000000000000000000 ?$ $000000000001 ? ? 00 ? 100100--0000000000 ? 02101--01010110000 ? 0 ? 00 ? 00111000-00000 ? 0 ? ? ? 00000000000000000 ? 00000 ?$ 10000 $00000110000 ? 001000 ? 01030 ? 22$ ? $1010000211101201 ? 0000010$ ? ?0?00??10021111?1211?????000?000?0?????100?0000?0 (1) $100000000001 / / 11-00041402 / 120000000 ? 0002 / / / / 0000000000 ? 0 ? 00 ? 110021100000 ? 001 ? ? ? 11111000000-00020 ? 0000 ? 0$ $00100110000 ? 00100000103002220201000 ? 2101012000 / 0000$ ????0??0?110021111??2?1?????0000?00?1??110021?0000? $1000000000022111-00041402 / 120001000 ? 000202 / 10000001000 ? 0 ? 00 ? 1 ? 0021 ? 00000 ? 0 ? ? ? ? ? 11111000000-00000 ? 0000 ? 0$ ???0011000?000210000104013-200111000021111201010000100001?0?1100?12-111211111110000000000?0010001001100 00000/210001202000003040-3-2001110000211112000000001010010001100211-11121111111000000000000?10101000000

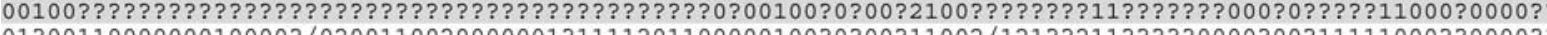
01 ? 0011000000010000 ?/0200110020000001?1111201100000100?0?00?11002/121??211?????0000?00?11111000??0000? $100001100001001010002040-3321001000002111220101110010000 ? 0001100211111211011 ? 1000000000000010 ? 01000000$ $0000011000110010 ? 000103003311001000 ? 0211112010 ? 100010000 ? 00 ? ? 10021111 ? ? 21111 ? ? 100000000000001010 ? 010000$ $00 ? 00110000100000000003001100101000 ? ? ? 0010100100 ? 00111 ? 0 ? 00 ? 110011111 ? ? ? 11 ? 1 ? ? ? ? 000000 ? 1 ? ? ? ? 1010 ? 00000$ 0000012100?100/1-0002040133?1001100002111120101110010000?0001100211-11121111?1100000000000001000?000000 0010022100000000001010400221000100002211112010000001011010001100111111121111111000000000110101011000000 0??0122?10002011-0001040?232010001/?221111201110000?00?0??0?110021111??211?1???0000?00??000?1010?0000?0 $1000022000012111-0002040-332000101000211112010101001000010001100211111121111101000000000000010001000000$ $00000 ? 100001000010002040-2320001000 ? 021111200 ? 1010010 ? 00 ? 00 ? 1100211113 ? 211 ? ? ? ? 10000 ? 00 ? 000001010 ? 0000 ? 0$ 01?0?111000??0???00????0-1220201000????????????00001???0?0??1100?/?2??121111???0000000111111100??0000?? $100001 / 00001100000003040-221000100000211123110001001000010111100111111121111111000000000001000001100010$

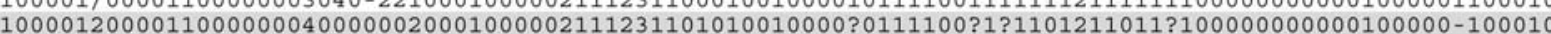
$0000122101002111-000103032220011011 ? 22111120101000010000 ? ? 0 ? 1100 ? 11111121111 ? ? 10000 ? 000000000010 ? 000000$ $0010 ? 00000 ?--? ?-200 ? 01-0-003--020000-00000100100010000 ? 0 ? 00 ? 1 ? 00 ? 2220 ? ? 1 ? ? 0 ? ? ? ? 0000011 ? 000-0100 ? ? 0000 ?$ $00000110000000000000 / 01001100100000010000120010000010000 ? 00 ? 1100111111121111 ? ? 100000000000000010 ? 000000$ $100000000000100000010000-0000000000000 ? 0020 ?-00010100001000021000000-000002000000010000000-0-0-0 ? 0000 ?$ $010011101001000000001030122 ? 0100010 ? 221011201110000100 ? 0 ? 00 ? 1 ? 0021111 ? ? 2 ? ? ? ? ? ? ? 0000 ? 00 ? 000000010 ? 0000 ? 0$ $010011101000000000001030122 / 010001 / 022101120011000010100 ? 00 ? 11002111111211 ? 1 ? ? 10000000 ? 000000010 ? 000000$ $0 ? ? 00220000000001000103001201 ? 01000 ? ? 10110100 ? 0000011 ? ? 0 ? 00 ? 110011111 ? ? 211 ? 1 ? ? ? 000000011 ? ? ? 0001 ? ? 0000 ? 0$ $100001 / 00001100000003020-2110001000002111231101010010000 ? 01 ? 110011 / 111 ? 211 ? 1 ? ? ? 0000 ? 00 ? 000001000 ? 100010$ $0010012100000000001010400221000100002 / 11112010000001011010001100111111121111111000000000100101101000000$ 10 ?00000?????---00-?--?-?0--00?000?-2?20010??0110100001?00?1?00??0--00010?11?00001?000?00-010???0000?0 $011002100000001 ? ? 00 ? 20 ? ? ? 32 ? 02000000 ? 21111200 ? 00000100 ? 0 ? 00 ? 21002 / 121112111 ? ? ? ? 00000001111110000 ? 000000$

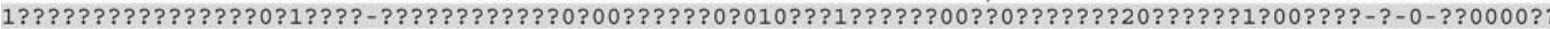
00000/2111112111-00010401232000101110211112010101001000001001100210111121111111000000000000010201000000 $0000012100010000200030401332001110000211112010000001010010000100212-11121111 ? 1100000000000-000101001100$ $0100112010110011-00010401222010001002210112010100002--00 ? ? 0 ? 11002111111211 ? ? ? ? 10000 ? 00 ? 000 ? 00010 ? 000000$

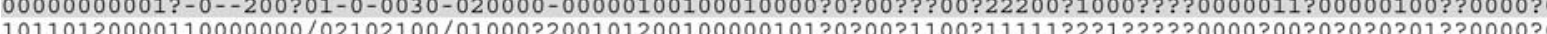
$0000000000000000000000 ? 004-00000000 ? 000000100100000000 ? 0 ? 00 ? 110001001 ? 021011 ? ? ? 00000000000000010 ? 0000 ?$

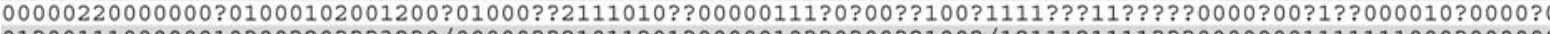
01 010011100000010?00?20???32?0/00000??21011201?0000010??0?00?:21002/1211121111??:00000001111111000?00000 $0000011 ? 00010011-00 ? ? 0 ? 0-3321001000 ? ? 21011201 ? ? 100010 ? ? 0 ? 00 ? 11002111111211 ? 1 ? ? ? 0000000 ? 0 ? 0 ? 010 ? 0 ? 000000$ $00000221000100000000101001100100000 ? 11000120010000010000 ? 00 ? 110021 / 111121111 ? ? 100000000000000010 ? 000000$ $1011022000000000 ? 000101101100001000022101120010000010 ? 00 ? 00 ? 11002111111211 ? ? ? ? ? 0000 ? 00 ? 0110000 / 0 ? 000001$ $0000022101102111-00010401232000101010211112010101001000001001100211111121111 ? 11000000000000010101000000$ 1000012000012111-0002040-33200010100021112311010?00100001000?101211111121111101000000000?00010001000000 $00100120000 ? 10 ? 010003010011 ? 0001000 ? 110110100 ? 0000011100 ? 00 ? 0100 ? 11111 ? 211 ? ? ? ? ? 0000000 ? 1 ? ? 000010 ? 000000$ $1000000000001000000040402 ? 22010000003 ? 0 ? 10100000 ? 01000 ? 0 ? 00 ? 100021 / 01 ? 00 ? 0 ? 1 ? ? 111111000000-0-020 ? 0000 ? 0$ 000000000000000000000000000000000000000000000000000000000000000000000000000000000000000000000000000000 ?

character state is not present in all members of the clade. The presence of hypurals 1 and 2 independent at their bases (120[2]) and a maxilla with a straight ventral margin (185[0]) are interpreted as synapomorphies at Node D4; however, Bavarichthys presents autapomorphic states for these two characters.

Many characters previously considered as synapomorphies of certain crossognathiform subgroups turn to be homoplastic because they are also present in other teleosts, especially the ichthyodectiforms (e.g., 93[1]), elopiforms (e.g., 54[0], 86[1], 114[1]), and clupeocephalans (e.g., 10[1], 46[1], 47[1], 105[1], 117[1] and 185[0]).

Some characters of the new fish are discussed below within the frame of crossognathiforms.

Infraorbital bones. Although the presence of five infraorbital bones seems to be common for crossognathiforms, the fusion among certain bones sets differences among groups. A few examples are given below:

1. Five independent infraorbital bones are present in the Late Jurassic varasichthyids and chongichthyids (Arratia 2008, figs 3, 6), in the Cretaceous Pachyrhi- zodus (Forey 1977, fig. 30), and Goulmimichthys (Cavin 2001, fig. 5).

2. Infraorbitals 1,4 and 5 free and $2+3$ fused is the pattern found in the Cretaceous Rhacolepis (Forey 1977, fig. 20). The bone interpreted as infraorbital $2+3$ occupies the position of independent infraorbitals 2 and 3 in other crossognathiforms.

3. Infraorbital 1 free and infraorbitals $2+3$ and $4+5$ fused is the pattern found in the Cretaceous Notelops (Forey 1977, fig. 6) and Michin (Alvarado-Ortega et al. 2008, fig. 2C). The bones interpreted as infraorbitals $2+3$ and $4+5$ occupy the positions of independent bones 2, 3, 4 and 5 in other crossognathiforms.

4. Infraorbital bones 1-3 independent and $4+5$ fused to each other (Fig. 4) is the pattern found in Bavarichthys incognitus gen. et $\mathrm{sp} . \mathrm{n}$.

5. By comparison with primitive teleosts, with independent posterior infraorbital bones (see for instance Arratia 1984, fig. 7), we interpret the pattern 1 as representative of the primitive condition and the patterns 2 to 4 as apomorphic conditions found in crossognathiforms. 
Infraorbital bones versus opercular bones. The posterior margins of infraorbital bones 3 and $4+5$ of Bavarichthys $\mathrm{n}$. gen. extend onto the anterior region of the preopercle. A similar extension of the posterior infraorbital bones onto the preopercle is present in varasichthyids and chongichthyids (Arratia 2008a, figs 3A, 6A) and in some pachyrhizodontoids like Notelops and Rhacolepis (Forey 1977, figs 6, 20). In contrast, the posterior margin of posterior infraorbitals 3-5 broadly extending onto the preopercle and opercle is the conditon found in crossognathids (e.g., Teller-Marshall \& Bardack 1978, fig. 8; Taverne 1989) and certain pachyrhizodontoids like Goulmimichthys (Cavin 2001, fig. 5), Michin (Alvarado-Ortega et al. 2008, fig. 2C), and Aquilopiscis (Cumbaa \& Murray 2008, fig. 7). An extension of the posterior infraorbitals onto the preopercle or the preopercle and opercle is not unique to crossognathiforms because some of the posterior infraorbitals extend onto the preopercle in various teleosts such some ichthyodectiforms (e.g., Patterson \& Rosen 1977, figs 3-5), elopiforms (Forey 1973, figs 6, 32; Arratia pers. obser. on different species of Elops and Megalops), and in the gonorhynchiform Chanos (Arratia pers. obser.)

Dermosphenotic. The dermosphenotic is not preserved in Bavarichthys incognitus, but according to the space left between the incomplete supraorbital bone, the autosphenotic, the pterotic and infraorbital $4+5$, the dermosphenotic may have been large. Information on the dermosphenotic of the basal Chongichthys is not available yet and this character was coded in the matrix with a question mark. However, the parsimony analyses interpret it as present in Chongichthys and Bavarichthys n. gen. Furthermore, this feature is also homoplastic because a large dermosphenotic is also present in ichthyodectiforms (e.g., Allothrissops; Patterson \& Rosen 1977, fig. 5) and some elopiforms (e.g., Elops; Arratia 1997 , fig. 36D).

Supramaxillary bones. Crossognathiforms may have one or two supramaxillary bones. Among crossognathiforms two supramaxillary bones are present in the Late Jurassic varasichthyids (Arratia 1981, 2008a; Arratia \& Schultze 1985) and in Bavarichthys n. gen. (Fig. 5) and in the Cretaceous crossognathids (Teller-Marshall \& Bardack 1978; Taverne 1989). Nevertheless, the two supramaxillary bones present in Bavarichthys have very different lengths: supramaxilla 1 is very long, whereas supramaxilla 2 is very short. In contrast, both bones are of similar lengths in varasichthyids and crossognathids. As far it is known, one supramaxillary bone is a feature found in chongichthyids (Arratia 1986, 2008a) and pachyrhizodontoids (e.g., Forey 1977; Maisey 1991a, 1991b; Cavin 2001).

Vertebral column and intermuscular bones. It is difficult to compare the vertebral column and intermuscular bones of Bavarichthys n. gen. with those present in other crossognathiforms. As far it is known, the count of vertebrae seems to be different among crosso- gnathiforms, especially pachyrhizodontoids. For instance, about 40 vertebrae have been described for Aquilopiscis (Cumbaa \& Murray 2008), and about 40 for Goulmimichthys, 26 of which are caudals (Cavin 2001). In contrast, 60 vertebrae, 19 or 20 caudals, have been described for Notelops and 55 to 65 vertebrae, about 20 caudals, were described for Rhacolepis (Forey 1977). Chongichthys has more than 60 vertebrae (last caudals are unknown), with approximately 40 abdominals preserved (Arratia 1982). Among crossognathids about 50 vertebrae - 35 abdominals and 15 caudals - are present in Crossognathus, whereas 12 to 14 caudals of a total of about 38-40 are present in Apsopelix (Patterson \& Rosen 1977). Bavarichthys incognitus n. gen. n. sp. with 18 or 19 caudal vertebrae of a total of about 53 or 54 vertebrae is closer to the high total count of vertebrae present in pachyrhizodontoids than the counts present in crossognathids. Additionally, the lower count of caudal vertebrae in Bavarichthys is closer to the condition present in pachyrhizodontoids than to crossognathids. High counts of vertebrae, including a greater number of abdominals in contrast to caudals, are also found in ichthyodectiforms and in elopiforms such as Elops and Megalops.

Bavarichthys n. gen. has more intermuscular bones than any other crossognathiform. It presents a series of long, delicate epicentrals in the abdominal region that has not been described in other crossognathiforms. A series of short, straight epicentral bones associated with the more anterior abdominal centra was described for $\mathrm{Ap}$ sopelix by Teller-Marshall \& Bardack (1978, p. 23). Bavarichthys presents an additional series of intermuscular bones (possible the "myorhabdoi" of Patterson \& Johnson 1995) dorsal to the epineurals in the caudal region and an extra series of long epipleural bones posterior to the series of small epipleurals. Because there is not much available information about intermuscular bones in crossognathiforms the phylogenetic meaning of these features cannot be addressed at the present time.

Hypurals. The total number of hypurals is very different among crossognathiforms so that comparisons and conclusions are difficult. Additionally, the total number of hypurals is unknown for many crossognathiforms due to conditions of preservation.

Varasichthyids seem to have the highest numbers of hypurals among crossognathiformes: 11 in Domeykos, 10 in Luisichthys, 9 in Protoclupea (Arratia 1991, 1997). Nine hypurals are also known from the crossognathid Crossognathus (Patterson \& Rosen 1977; Taverne 1989). The total number of hypurals of pachyrhizodontoids is unknown for most species, but six hypurals are reported for Notelops (Maisey 1991b, p. 267) and Goulmimichthys (Cavin 2001).

The hypurals in crossognathiforms may be fused to each other in different groups. Hypurals are unfused between each other in varasichthyids. Hypurals 1 and 2 
and parhypural and hypural 1 (Fig. 11) are partially fused to each other in Bavarichthys n. gen. In contrast, hypurals $1+2$ and $3+4$ are fused in Notelops (Maisey 1991b); hypurals $1+2$ and 3 plus other upper hypurals are fused in Pachyrhizodus caninus (Forey 1977), and hypurals $1+2$ and $3+4$ are fused in Goulmimichthys (Cavin 2001). Only hypurals $1+2$ are fused in Crossognathus (Taverne 1989). The pattern present in Bavarichthys, showing incomplete lines of fusion between hypurals 1 and 2 may represent the primitive condition found in members of the unnamed clade (Fig. 12: node D3). However, this hypothesis should be tested when the caudal fin of Chongichthys becomes known. The partial fusion between parhypural and hypural 1 seems to be unique to Bavarichthys n. gen.

Basal fulcra. Bavarichthys incognitus n. gen. n. sp. presents a complete series of epaxial basal fulcra, a retention of the primitive condition found in teleosteomorphs. According to the available restorations of crossognathiforms in the literature, it seems that most pachyrhizodontoids and crossognathids present epaxial precurrent (or procurrent) rays instead of basal fulcra. However, and due to the lack of detailed descriptions of the epaxial series of elements of the caudal fin of many crossognathiforms, conclusions concerning presence versus absence of basal fulcra in crossognathiforms are not possible.

In conclusion, numerous characters are difficult to compare due to the fact that many are incompletely known in crossognathiforms and others are ambiguous. Yet despite these difficulties, the morphological information of Bavarichthys incognitus and the description of its characters justify its inclusion in a new genus and species within crossognathiforms. It is important to note that numerous features described herein were available to study only when the material was exposed to ultraviolet techniques.

\section{Acknowledgements}

We thank Hans-Peter Schultze (Lawrence), for comments on the manuscript, Günter Schweigert (Stuttgart) and Günter Viohl (Eichstätt) for discussions concerning the age of the locality, Martina Kölbl-Ebert (Eichstätt), Lance Grande (Chicago), and Larry Martin (Lawrence) for facilities to study material under their care, Carmen Chang-Arratia (New York) for improving the style of the manuscript. The supports of a National Geographic grant and a visiting - research grant (G. Arratia) from the Field Museum of Natural History are greatly appreciated. The manuscript was reviewed by Lionel Cavin (Geneve), Eric Hilton (Gloucester Point), and Louis Taverne (Brussels).

\section{References}

Agassiz, L. 1833-1844. Recherches sur les Poissons Fossiles. 5 vols., Petitpierre, Neuchâtel et Soleure, Switzerland.

Alvarado-Ortega, J., Mayrinck. D. de \& Brito, P. 2008. A basal pachyrhizodontid fish (Actinopterygii, Teleostei) from the Lower Cretaceous of the Tlayúa Quarry, Central Mexico. - Comptes Rendus Palevol 7: 269-275.
Arratia, G. 1981. Varasichthys ariasi n. gen. et sp. from the Upper Jurassic of Chile (Pisces, Teleostei, Varasichthyidae). - Palaeontographica A 175: 107-139.

Arratia, G. 1982. Chongichthys dentatus, new genus and species from the Late Jurassic of Chile (Pisces, Teleostei: Chongichthyidae, new family). - Journal of Vertebrate Paleontology 2: 133-149.

Arratia, G. 1984. Some osteological features of Varasichthys ariasi ARRATIA (Pisces, Teleostei) from the Late Jurassic of Chile. Paläontologische Zeitschrift 58 (1/2): 149-163.

Arratia, G. 1986. New Jurassic fishes of Cordillera de Domeyko, Northern Chile. - Palaeontographica A 192: 75-91.

Arratia, G. 1991. The caudal skeleton of Jurassic teleosts; a phylogenetic analysis. In Chang, M.-M., Liu, Y.-H. \& Zhang, G.-R. (eds). Early Vertebrates and Related Problems in Evolutionary Biology. Science Press, Beijing: pp. 249-340.

Arratia, G. 1992. Development and variation of the suspensorium of primitive Catfishes (Teleostei: Ostariophysi) and their phylogenetic relationships. - Bonner zoologische Monographien 32: 1-149.

Arratia, G. 1996. Reassessment of the phylogenetic relationships of certain Jurassic teleosts and their implications on teleostean phylogeny. In Arratia, G. \& Viohl, G. (eds). Mesozoic Fishes - Systematics and Paleoecology. Verlag Dr. F. Pfeil, München: pp. 219242 .

Arratia, G. 1997. Basal teleosts and teleostean phylogeny. - Palaeo Ichthyologica 7: 1-168.

Arratia, G. 1999. The monophyly of Teleostei and stem-group teleosts. Consensus and disagreements. In Arratia, G. \& Schultze, H.-P. (eds). Mesozoic Fishes 2 - Systematics and Fossil Record. Verlag Dr. F. Pfeil, München: pp. 265-334.

Arratia, G. 2000. Remarkable teleostean fishes from the Late Jurassic of southern Germany and their phylogenetic relationships. - Mitteilungen aus dem Museum für Naturkunde in Berlin, Geowissenschaftliche Reihe 3: 137-179.

Arratia, G. 2008a. The varasichthyid and other crossognathiform fishes, and the break-up of Pangaea. In Cavin, L., Longbottom, A. \& Richter, M. (eds). Fishes and the break-up of Pangaea: Special Publication 295. Geological Socociety, London: pp. 71-92.

Arratia, G. 2008b. Actinopterygian postcranial skeleton with special reference to the diversity of fin ray elements, and the problem of identifying homologies. In Arratia, G., Schultze, H.-P. \& Wilson, M. V. H. (eds). Mesozoic Fishes 4 - Homology and Phylogeny. Verlag Dr. Pfeil, München: pp. 49-101.

Arratia, G. 2009. Identifying patterns of diversity of the actinopterygian fulcra. - Acta Zoologica, Stockholm 90: 220-235.

Arratia, G. \& Gayet, M. 1995. Sensory canals and related bones of Tertiary siluriform crania from Bolivia and North America and comparison with Recent form. - Journal of Vertebrate Paleontology 15: 482-505.

Arratia, G. \& Schultze, H.-P. 1985. Late Jurassic teleosts (Actinopterygii, Pisces) from Northern Chile and Cuba. - Palaeontographica A 189: 29-61.

Arratia, G. \& Schultze, H.-P. 1990. The urohyal: Development and homology within osteichthyans. - Journal of Morphology 203: $247-382$.

Arratia, G. \& Schultze, H.-P. 1991. Development and homology of the palatoquadrate in osteichthyans. - Journal of Morphology 208: $1-81$.

Arratia, G. \& Schultze, H.-P. 1992. Reevaluation of the caudal skeleton of certain actinopterygian fishes. III. Salmonidae. Homologization of caudal skeletal structures. - Journal of Morphology 214: 1-63.

Arratia, G. \& Schultze, H.-P. 1999. Mesozoic fishes from Chile. In Arratia, G. \& Schultze, H.-P. (eds). Mesozoic Fishes 2 - Systematics and Fossil Record. Verlag Dr. F. Pfeil, München: pp. 565-593.

Blanco, A. \& Cavin, C. 2003. New Teleostei from the Agua Nueva Formation (Turonian), Vallecito (NE Mexico). - Comptes Rendus Palevol 2: 299-306. 
Brito, P. M. 1997. Révision des Aspidorhynchidae (Pisces, Actinopterygii) du Mésozoïque: ostéologie, relations phylogénétiques, donnés environmentals et biogéographiques. - Geodiversitas 19: $681-772$.

Brito, P. M. \& Ebert, M. 2009. A new aspidorhynchid fish (Teleostei: Aspidorhynchiformes) from the Upper Jurassic of Ettling, Solnhofen, Bavaria, Germany. - Comptes Rendus Palevol 8: 395-402.

Cavin, L. 2001. Osteology and phylogenetic relationships of the teleost Goulmimichthys arambourgi Cavin, 1995, from the Upper Cretaceous of Goulmima, Morocco. - Eclogae Geologicae Helvetiae 94: 509-535.

Cavin, L. \& Grigorescu, D. 2005. A new Crossognathus (Actinopterygii, Teleostei) from the Lower Cretaceous of Romania with comments on Crossognathidae relationships. - Geodiversitas 27: 516

Chen, X.-Y. \& Arratia, G. 1994. Olfactory organ in Acipenseriformes and comparison with other actinopterygians: patterns of diversity. - Journal of Morphology 222: 241-267.

Cope, E. D. 1872. On the families of fishes of the Cretaceous formation in Kansas. - Proceedings of the American Philosophical Society, Philadelphia 12: 327-357.

Cope, E. D. 1887. Zittel's Manual of Paleontology. - American Naturalist 17: 1014-1019.

Cumbaa, S. L. \& Murray, A. M. 2008. New Late Cretaceous pachyrhizodontoid fishes and associated ichthyofauna from the Northwest territories, Canada. In Arratia, G., Schultze, H.-P. \& Wilson, M. V. H. (eds). Mesozoic Fishes 4 - Homology and Phylogeny. Verlag Dr. F. Pfeil, München: pp. 229-256.

Dixon, D. H. 1850. The geology and fossils of the Tertiary and Cretaceous formations of Sussex. F. Dixon, London.

Dunkle, D. H. 1940. The cranial osteology of Notelops brama (Agassiz), an elopid from the Cretaceous of Brazil. - Looydia, Cincinnati, Ohio 3: 157-190.

Ebert, M. \& Kölbl-Ebert, M. 2008. Steinbruch Ettling (Markt Pförring) - eine neue wissenschaftliche Grabungsstelle des JuraMuseums Eichstätt. - Archaeopteryx 26: 61-74.

Fink, S. \& Fink, W. 1981. Interrelationships of ostariophysan fishes (Teleostei). - Zoological Journal of the Linnean Society, London 72: $297-358$

Fink, S. \& Fink, W. 1996. Interrelationships of ostariophysan fishes. In Stiassny, M. L. J., Parenti, L. R. \& Johnson, D. G. (eds). Interrelationships of Fishes. Academic Press, San Diego: pp. 209-249.

Forey, P. L. 1973. A revision of the elopiform fishes, fossil and Recent. - Bulletin of the British Museum (Natural History), Geology, Supplement 10: 4-222.

Forey, P. L. 1977. The osteology of Notelops Woodward, Rhacolepis Agassiz and Pachyrhizodus Dixon (Pisces: Teleostei). - Bulletin of the British Museum of Natural History, Geology 28: 125-204.

Grande, L. 1985. Recent and fossil clupeomorph fishes with materials for revision of the subgroups of clupeids. - Bulletin of the American Museum of Natural History 181: 231-272.

Grande, L. \& Bemis. W. 1998. A comprehensive phylogenetic study of amiid fishes (Amiidae) based on comparative skeletal anatomy. An empirical search for interconnected patterns of natural history. Journal of Vertebrate Paleontology 18, supplement 1, Memoir 4: $1-609$.

Hennig, W. 1966. Phylogenetic Systematics. University of Illinois Press, Urbana, Chicago, London.

Jessen, H. 1972. Schultergürtel und Pectoralflosse bei Actinopterygiern. - Fossils and Strata 1: 1-101.

Johnson, G. D. \& Patterson, C. 1996. Relationships of lower euteleost fishes. In Stiassny, M. L. J., Parenti, L. R. \& Johnson, D. G. (eds). Interrelationships of Fishes. Academic Press, San Diego: pp. $251-332$.

Jordan, D. S. \& Branner, J. C. 1908. The Cretaceous fishes of Ceará, Brazil. - Smithsonian Miscellaneous Collections, Washington 52: 1-30
Lauder, G. V. \& Liem, K. 1993. The evolution and interrelationships of the actinopterygian fishes. - Bulletin of the Museum of Comparative Zoology, Harvard University 150: 95-197.

Lecointre, G. \& Nelson, G. J. 1996. Clupeomorpha, sister group of Ostariophysi. In Stiassny, M. L. J., Parenti, L. R. \& Johnson, D. G. (eds). Interrelationships of Fishes. Academic Press, San Diego: pp. 193-207.

Li, G.-Q. \& Wilson, M. V. H. 1996. Phylogeny of Osteoglossomorpha. In Stiassny, M. L. J., Parenti, L. R. \& Johnson, D. G. (eds). Interrelationships of Fishes. Academic Press, San Diego: pp. 163-174.

Loomis, F. 1900. Die Anatomie und die Verwandtschaft der Ganoidund Knochen Fische aus der Kreide-Formation von Kansas. Palaeontographica 46: 213-284, pls.19-27.

Maisey, J. 1991a. Rhacolepis Agassiz, 1841. In Maisey, J. (ed.) Santana Fossils, An Illustrated Atlas, T. F. H. Publications, Inc., Neptune City: pp. 248-257.

Maisey, J. 1991b. Notelops Woodward, 1901. In Maisey, J. (ed.) Santana Fossils, An Illustrated Atlas. T.F.H. Publications, Inc., Neptune City: pp. 258-271.

Meyer, R. K. F. 2001. Geologische Karte von Bayern 1: 25000, Blatt 7135 Kösching. Bayerisches Geologisches Landesamt; München.

Meyer, R. K. F. 2003. Geologische Karte von Bayern 1: 25000, Erläuterungen zum Blatt 7135 Kösching. Bayerisches Geologisches Landesamt; München.

Meyer, R. K. F. \& Schmidt-Kaler, H. 1983. Erdgeschichte sichtbar gemacht. Ein geologischer Führer durch die Altmühlalb. Bayerisches Geologisches Landesamt; München. 260 pp., 260 figs.

Meyer, R. K. F. \& Schmidt-Kaler, H. 1989. Paläogeographischer Atlas des süddeutschen Oberjura (Malm). - Geologisches Jahrbuch 115: 3-77.

Mainwaring, A. J. 1978. Anatomical and systematic revision of the Pachycormidae, a family of Mesozoic fossil fishes. Ph.D. Thesis, Westfield College, London.

Nelson, G. J. 1969. Infraorbital bones and their bearing on the phylogeny and geography of osteoglossomorph fishes. - American Museum Novitates 2394: 1-37.

Patterson, C. 1973. Interrelationships of holosteans. In Greenwood, P. H., Miles, R. S. \& Patterson, C. (eds). Interrelationships of Fishes. - Zoological Journal of the Linnean Society, Supplement 1: 233-305.

Patterson, C. 1977. The contribution of paleontology to teleostean phylogeny. In Hecht, P. C., Goody, P. C. \& Hecht, B. M. (eds). Major Patterns in Vertebrate Evolution. Plenum Press, New York: pp. 579-643.

Patterson, C. 1993. Osteichthyes: Teleostei. In Benton, M. (ed.). The Fossil Record. Chapman \& Hall, London, Glasgow, New York, Tokyo, Melbourne, Madras: pp. 621-663.

Patterson, C. \& Johnson, G. D. 1995. The intermuscular bones and ligaments of teleostean fishes. - Smithsonian Contributions to Zoology 559: 83 pp.

Patterson, C. \& Rosen, D. E. 1977. Review of the ichthyodectiform and other Mesozoic teleost fishes and the theory and practice of classifying fossils. - Bulletin of the American Museum of Natural History 158: 83-172.

Patzelt, W. 1963. Verbreitung, Gliederung und Lagerung des Malm auf den Kartenblättern Kösching und Vohburg (Südliche Frankenalb). - Erlanger geologische Abhandlungen 50: $12 \mathrm{pp}$.

Pictet, F. J. 1858. Description des fossiles contenus dans le terrain néocomian des Voirons. Troisième partie. - Matériaux pour la paléontologie suisse, ou recueil des monographies sur les fossiles des Jura et des Alpes, série 2 (1), pt. 3: 54 pp.

Pinna, M. de. 1996. Teleostean monophyly. In Stiassny, M. L. J., Parenti, L. R. \& Johnson, D. G. (eds). Interrelationships of Fishes. Academic Press, San Diego: pp. 147-162.

Poyato-Ariza, F. J. 1996. A revision of the ostariophysan family Chanidae, with special reference to the Mesozoic forms. - Palaeo Ichthyologica 6: 5-52. 
Schnitzer. W. A. 1965. Die Geologie des Weißen Jura auf den Blättern Kipfenberg und Gaimersheim (Südliche Frankenalb). - Erlanger geologische Abhandlungen 57: 45 pp.

Schultze, H.-P. 1996. The scales of Mesozoic actinopterygians. In Arratia, G. \& Viohl, G. (eds). Mesozoic Fishes - Systematics and Paleoecology. Verlag Dr. F. Pfeil, München: pp. 243-259.

Schultze, H.-P. \& Arratia, G. 1986. Reevaluation of the caudal skeleton of actinopterygian fishes. I. Lepisosteus and Amia. - Journal of Morphology 195: 257-303.

Schultze, H.-P. \& Arratia, G. 1989. The composition of the caudal skeleton of teleosts (Actinopterygii, Osteichthyes). - Zoological Journal of the Linnean Society 97: 189-231.

Schweigert, G. 2007. Ammonite biostratigraphy as a tool for dating Upper Jurassic Lithographic limestones from South Germanyfirst results and open questions. - Neues Jahrbuch für Geologie und Paläontologie, Abhandlungen 245 (1): 117-125.

Silva Santos, R. de \& Valença, J. G. 1968. A formaçao Santana e sua paleoictiofauna. - Anais de la Academia Brasileira de Ciencias, Rio de Janeiro 40: 339-360.

Stiassny, M. L. J. 1986. The limits and relationships of the acanthomorph teleosts. - Journal of Zoology B1: 411-460.

Swofford, D. L. 2005. PAUP*: Phylogenetic analysis using parsimony (* and other methods), version 4.0 Beta, Sinauer Associates, Sunderland, Massachusetts.

Taverne, L. 1980. Ostéologie et position systématique du genre Platinx (Pisces, Teleostei) de l' éocène du Monte Bolca (Italie). Académie Royale de Belgique, Bulletin de la Classe des Sciences, 5. série, 66: 873-889.

Taverne, L. 1989. Crossognathus Pictet, 1858 du Crétacé inférieur de l'Europe et systématique, paleozoogéographie et biologie des
Crossognathiformes nov. ord. (Téléostéens) du Crétacé et du Tertiaire. - Palaeontographica A 207: 79-105.

Taverne, L. 2008. Les poisons crétacés de Nardò. 29 . Nardopiscis cavini gen. et sp. nov. (Teleostei, Crossognathiformes, Pachyrhizodontidae). - Bolettino del Museo civico di Storia Naturale di Verona 32, Geologia Paleontologia Preistoria: 19-28.

Teller-Marshall, S. \& Bardack, D. 1978. The morphology and relationships of the Cretaceous teleost Apsopelix. - Fieldiana, Geology 41: 1-35.

Tischlinger, H. 1992. Zwischen Tropensonne und Kältesteppe. In Markt Pförring (ed.): Pförring - 1850 Jahre Römerort Celeusum. Hercynia, Kipfenberg: 9-48.

Tischlinger, H. 1998. Erstnachweis von Pigmentfarben bei Plattenkalk-Teleosteern. - Archaeopteryx 16: 1-16.

Tischlinger, H. 2002. Der Eichstätter Archaeopteryx im langwelligen UV-Licht. - Archaeopteryx 20: 21-38.

Tischlinger, H. 2005. Ultraviolet Light Investigations of Fossils from the Upper Jurassic Plattenkalks of Southern Frankonia. - Zitteliana B 26: 26

Viohl, G. 1996. The paleoenvironment of the Late Jurassic fishes from the southern Franconian Alb (Bavaria, Germany). In Arratia, G. \& Viohl, G. (eds). Mesozoic Fishes - Systematics and Paleoecology. Verlag Dr. F. Pfeil, München: pp. 513-528.

Wenz, S. 1965. Les poissons albiens de Vallentigny (Aube). - Annales de Paléontologie, Paris 51: 3-23.

Woodward, A. S. 1901. Catalogue of the fossil fishes in the British Museum (Natural History), 4. British Museum (Natural History), London.

Zeiss, A. 1977. Jurassic stratigraphy of Franconia. - Stuttgarter Beiträge zur Naturkunde B 31: 1-32. 


\section{Appendix}

\section{List of characters}

Numbers in brackets () correspond to numbers of characters in Arratia (2008). $\dagger$ indicates that a taxon is extinct; [0] represents the plesiomorphic character state and [1], [2], [3] and [4] the apomorphic character states. Seventeen characters were deleted from Arratia's (2008a: characters $15,58-60,62,77,83,114,115,119,126,134,168,169$, 175 and 185) because of ambiguous description or incomplete knowledge of the development of the structures involved. A few characters were modified from their original presentation; these changes are identified in the list of characters (see below) and other are new (e.g., characters $57-59,61,120,128,184-193)$.

1. (1) Ethmopalatine ossification in the floor of the nasal capsule articulating with autopalatine: absent [0]; present [1].

2. (2) Two paired endoskeletal ethmoidal ossifications: absent [0]; present [1].

3. (3) Postparietal (= so-called parietal) bones: independent [0]; fused to each other [1]; fused with dermopterotic or pterotic [2].

4. (4) Supraoccipital bone: absent [0]; present [1]. (Modified from Arratia 1999, 2000).

5. (5) Basisphenoid: present [0]; absent [1].

6. (6) Sutures between cartilage bones in the braincase retained throughout life, rather than being lost ontogenetically: absent [0]; present [1]. (Patterson \& Rosen 1977).

7. (7) Suture between parietal bones (= so-called frontals) smooth (sutura armonica): present [0]; absent [1].

8. (8) Orbitosphenoid bone: reduced or absent [0]; large [1]. (Modified character from Arratia 1999, 2008a).

9. (9) Orbitosphenoid partially or completely reaching the parasphenoid ventrally: absent [0]; present [1].

10. (10) Parasphenoid: with small teeth [0]; toothless [1]; with large teeth [2].

11. (11) Parasphenoid long, extending posterior to basioccipital: absent [0]; present [1]. (Modified from Arratia 2000).

12. (12) Ossified aortic canal: present [0]; absent [1].

13. (13) Canals for occipital arteries in basioccipital bone: present [0]; absent [1].

14. (14) Spiracular canal: well developed [0]; greatly reduced [1]; absent [2].

15. (16) Posterior myodome: bone-enclosed [0]; opens posteriorly [1]. (Patterson 1977)

16. (17) Recessus lateralis: absent [0]; present [1].

17. (18) Otophysic connection involving a diverticulum of the swimbladder that penetrates the exoccipital and extends into the prootic within the lateral wall of the braincase: absent [0]; present [1]. (Patterson \& Rosen 1977; Grande 1985).

18. (19) Pre-epiotic fossa: absent [0]; present [1].

19. (20) Foramen for glossopharyngeal nerve in exoccipital: absent [0]; present [1]. (Patterson \& Rosen 1977).

20. (21) Foramen for vagus nerve placed in postero-lateral face of exoccipital alone: absent [0]; present [1].

21. (22) Cephalic sensory canal components: continuous [0]; interrupted between them [1]

22. (23) Cephalic sensory canals with: branched tubules [0]; simple tubules [1]; reduced or no tubules [2]. (Modified from Arratia 2000, 2008a).

23. (24) Antorbital bone: carrying a portion of the infraorbital canal [0]; without sensory canal [1]. (Modified from Arratia 2000).

24. (25) An ethmoidal commissure that penetrates and passes through the whole width of a broad mesethmoid: absent [0]; present [1].

25. (26) Middle pit-line groove crossing the dermopterotic (or pterotic): present [0]; absent [1].

26. (27) Supratemporal commissure (primitively) passing through postparietals or through postparietals (= so called parietal) and supraoccipital: absent [0]; present [1]. (Patterson \& Rosen 1977; Grande 1985).

27. (28) Ankylosis or fusion between the mesial extrascapula and postparietal alone or postparietal (= so-called parietal) and supraoccipital; absent [0]; present [1]. (Arratia \& Gayet 1995; modified from Lecointre \& Nelson 1996).

28. (29) A narrow tube-like infraorbital 1 or a broad antorbital plus infraorbital 1 combined with enlarged bone(s) representing the third and fourth and/or fourth and fifth of other teleosts: absent [0]; present [1].

29. (30) Fourth and fifth infraorbital bones: separate [0]; fused forming an expanded bone [1].

30. (31) Suborbital bone(s): Numerous [0]; two or three [1]; one [2]; none [3].

31. (32) Supraorbital bone(s): more than two [0]; two [1]; one [2]; fused with other bone forming the supraorbito-dermosphenotic [3].

32. (33) Large supraorbital bone with expanded antero-ventral portion: absent [0]; present [1].

33. (34) Comma-shaped antorbital bone: absent [0]; present [1]

34. (35) Toothed dermopalatine bone(s): present [0]; absent [1].

35. (36) Autopalatine bone: ossifies late in ontogeny [0]; ossifies early in ontogeny [1]. (Arratia \& Schultze 1991).

36. (37) Elongation of suspensorium: "normal", no special elongation [0]; parasagittal elongation due to separation between quadrate and hyomandibula and elongation of symplectic [1] (after Fink \& Fink 1981; Arratia, 1992); partial elongation due to enlargement of quadrate and symplectic and the separation between the long and narrow ventral part of the hyomandibula and symplectic [2]. (Modified from Arratia 2000).

37. (38) Elongation of the suspensorium due to the ventro-posterior inclination of the hyomandibula: absent [0]; present [1].

38. (39) Hyomandibular bone with a preopercular process at its posterior margin: absent [0]; present [1].

39. (40) Elongate lower jaw bearing numerous villiform teeth: absent [0]; present [1].

40. (41) Upper and lower jaws: with teeth [0]; without teeth [1].

41. (42) Very broad, concave-convex premaxilla: absent [0]; present [1]. (Poyato-Ariza 1996).

42. (43) Articular process of maxilla very long and irregularly shaped: absent [0]; present [1].

43. (44) Dentated maxilla: present [0]; absent [1]; other condition: maxilla and infraorbital bones fused [2].

44. (45) Supramaxilla(ae): placed dorsal to the dorsal margin of maxilla [0]; placed posterior to maxilla [1]. (Modified from Arratia 1999, 2000).

45. (46) Quadrate-mandibular articulation: posterior to orbit [0]; placed below the posterior half of orbit [1]; below anterior half of orbit [2]; anterior to orbit [3].

46. (47) Retroarticular bone: included in the joint facet for quadrate [0]; excluded from the joint facet for quadrate [1]; retroarticular bone absent or not present as an independent bone [2]. (Modified from Arratia 1999, 2008a).

47. (48) Articular bone: not fused to angular and retroarticular [0]; fused with both angular and retroarticular bones [1]; fused with angular [2]; partially fused with anguloretroarticular late in ontogeny [3].

48. (49) Postarticular process of lower jaw: poorly developed [0]; well developed, extending posterior to the articular facet for quadrate [1]. (Modified from Arratia 1999, 2008a).

49. (50) Characteristic notch (so-called leptolepid notch) in the deep dorsal ascending margin of the dentary: absent [0]; present [1].

50. (51) Posterior opening of the mandibular sensory canal: placed medial or posterior to angular portion of the jaw [0]; placed lateral to the angular portion of the jaw [1].

51. (52) Posterior section of the mandibular canal: present [0]; absent [1]. 
52. (53) Mandibular canal enclosed in bone along the whole lower jaw: present [0]; or mandibular canal partially running in a tube bone and a groove [1].

53. (54) Elongate posteroventral process of quadrate: absent [0]; present [1]. (Arratia \& Schultze 1991).

54. (55) Gular plate: present [0]; absent [1].

55. (56) Hyoidean artery piercing ventral hypohyals: absent [0]; present [1]. (Modified from Arratia 2008a).

56. (57) Basibranchials 1-3 and basihyal cartilages overlain by median tooth plate(s): present [0]; absent [1]. (Lauder \& Liem 1993).

57. Tooth plate(s) associated (attached, ankylosed or fused) to pharyngobranchial 1: present [0]; absent [1].

58. Tooth plate(s) associated (attached or fused) to pharyngobranchial 2 : present [0]; absent [1].

59. Tooth plate(s) associated (attached or fused) to pharyngobranchial 3: present [0]; absent [1].

60. (62) Toothplate of last pharyngobranchial element formed by: confluence of many tooth-plates [0]; growth of one toothplate [1].

61. Independent endoskeletal basihyal: absent [0]; present [1]; other condition [2].

62. (63) Suprapreopercle: absent [0]; present [1].

63. (64) Ventro-posterior (excluding dorsal limb) region of preopercle: narrow or slightly expanded [0]; broadly expanded [1].

64. (65) Preopercular sensory canal with many tubules in ventral limb reaching ventral and ventroposterior margin of the bone: absent [0]; present [1].

65. (66) Preopercular sensory canal with four or fewer short and simple tubules placed in the ventral limb of the bone: absent [0]; present [1].

66. (67) Distinctively enlarged preopercle with a long ventral arm: absent [0]; present [1].

67. (68) Irregular parallelogram, or oval, or kidney-shaped opercular bone: absent [0]; present [1]. (Li \& Wilson 1996).

68. (69) Opisthocoelus centra with a convex articular surface and a concave posterior articular surface: absent [0]; present [1].

69. (70) Each vertebral centrum of the caudal region of adult individuals formed by: mineralized chordacentrum and arcocentra [0]; chordacentrum and basal part of arcocentra surrounded by autocentrum [1]; basal part of arcocentra surrounded by autocentrum [2].

70. (71) Vertebral autocentra: absent [0]; present: thin and smooth [1]; or thick and sculptured [2]; or thick and smooth [3]. (Modified from Arratia 1991, 1997).

71. Vertebral autocentrum: absent [0]; present: without cavities for adipose tissue [1]; with cavities for adipose tissue [2].

72. Vertebral autocentra: absent [0]; not constricting the notochord [1]; strongly constricting the notochord [2].

73. (74) Neural arches of the abdominal region: not fused to the centra [0]; fused, except for the first five or six [1]

74. (75) Dorso-medial portions of the anterior neural arches expanded and abutting against each other and the posterior margin of the exoccipital; absent [0]; present [1]. (Fink \& Fink 1981, 1996).

75. (76) Neural arches of most abdominal vertebrae: with separate halves of the neural arch [0]; with fused halves of the neural arch forming a median neural spine [1].

76. (78) Anterior pleural rib, on third vertebra, is distinctly larger than the next few ribs: absent [0]; present [1]. (Fink \& Fink 1981, 1996)

77. (79) Neural spines of caudal region: paired [0]; unpaired [1].

78. (80) Interhaemal bones: present [0]; absent [1].

79. (81) The first supraneural anterior to the neural spine of vertebra 1 develops independently, and the remainders differentiate in rostral and caudal gradients from a focus midway between the occiput and dorsal fin origin: absent [0]; present [1]. (Johnson \& Patterson 1996).
80. (82) In adult individuals, elongate, solid epineural processes of neural arch of abdominal vertebrae: absent [0]; present [1]; another condition: a separate bone joined to the neural arch by a ligament [2].

81. (84) Epipleural intermuscular bones: absent [0]; few bones in the anterior caudal region only [1]; many bones developed in the abdominal and anterior caudal region [2].

82. (85) Complex epipleural bones: absent [0]; present [1]

83. (86) Series of dorsal intermuscular bones throughout caudal region: absent [0]; present [1].

84. (87) Supracleithrum with main lateral line emerging: at its upper half [0]; at its most posteroventral margin [1]; lateral line not running through the supracleithrum [2].

85. (88) Postsupracleithrum(ra): absent [0]; present [1].

86. (89) Postcleithra: one to three [0]; four or more [1]; none [2].

87. (90) Coracoid bone enlarged ventrally meeting its fellow in a midventral coracoid symphysis: absent [0]; present [1]. (Patterson \& Rosen 1977).

88. (91) Pectoral propterygium fused with first pectoral ray: absent [0]; present [1]. (Jessen 1972; Patterson 1977)

89. (92) Pectoral axillary process: absent [0]; present; formed by small bony elements [1]; present; formed by an elongate bony element [2]; present; formed by modified scales [3].

90. (93) Pelvic axillary process: absent [0]; present; formed by an elongate bone [1]; present; formed by a combination of bony element(s) and modified scales [2]; present; formed by modified scales [3].

91. (94) Dorsal and anal fins posteriorly placed: absent [0]; present [1]

92. (95) Dorsal fin origin anterior to that of pelvic fin: absent [0]; present [1]

93. Dorsal fin acuminate: absent [0]; present [1]

94. (97) Anal fin long, falcate, opposed by a short, remote dorsal fin: absent [0]; present [1]. (Patterson \& Rosen 1977).

95. (98) First anal pterygiophore placed posterior to fourth or fifth haemal spine: absent [0]; present [1]

96. (99) Preural vertebrae (without preural centrum 1) of adult individuals with haemal arches; autogenous [0]; laterally fused to their respective autocentra [1]; not fused laterally to their autocentra [2].

97. (100) Parhypural (in adults) with haemal arch: autogenous [0]; laterally fused to its autocentrum [1]; laterally not fused to its autocentrum [2].

98. (101) Hypurapophysis: absent [0]; present [1].

99. (102) Neural spine of vertebrae 5-3 distally expanded by fine anterior and posterior membranous outgrowths; absent [0]; present [1].

100. (103) Neural spines of at least preural vertebrae 4-2 with membranous outgrowths and leaf-like: absent [0]; present [1]

101. (104) Neural spine of preural vertebra 3: inclined toward the horizontal at an angle of less than 45 degrees in relation to the dorsal margin of the centra [0]; inclined toward the horizontal at an angle of over 45 degrees [1].

102. (105) Neural spine of preural centrum 2: shorter than neural spine of preural centrum 3 [0]; as long as neural spine of preural centrum 3 [1]; neural spine absent [2].

103. (106) Neural spine of preural centrum 1: rudimentary or short [0] long, close to, or reaching the dorsal margin of the body [1]; absent [2].

104. (107) Neural arch on preural centrum 1: present [0]; absent or atrophic [1]

105. (108) Neural spine of ural centra 1 and 2 or 'first' ural centrum present [0]; absent [1]; other condition: preural centrum 1 fused with ural centrum(ra) [2]

106. (109) Neural arch of ural centra 1 and 2 or 'first' ural centrum: present [0]; absent [1]; other condition: fusion of elements [2]. 
107. (110) Neural arch over 'first' ural centrum: complete [0]; reduced [1]; other condition: fusion of elements [2].

108. (111) A mass of cartilage, or uroneural cartilage, apparently originated by fusion of cartilaginous neural arches: absent [0]; present [1].

109. (112) A compound neural arch formed in a mass of cartilage over preural centrum 1 and ural centra: absent [0]; present [1]. (Modified from Patterson \& Rosen 1977).

110. (113) Ural centra (originated only) as expansion of the dorsal arcualia: absent [0]; present [1]. (Schultze \& Arratia 1986, 1989).

111. (117) Number of epurals: four or more [0]; three [1]; two [2]; one [3]; none [4].

112. (117) Some preural neural arches modified as uroneural-like bones: absent [0]; present [1].

113. (118) Number of ural neural arches modified as uroneurals: none [0]; seven or more [1]; six [2]; five or four [3]; three or less [4].

114. (120) Six or seven uroneurals, the first three or four extending antero-ventrally to cover the entire lateral surface of the first, second and third preural centra: absent [0]; present [1].

115. Uppermost uroneurals ( $=5$ to 7 of primitive teleosts) forming a series that overlaps and lies at an angle to, longer anterior ones: [0] absent; present [1].

116. (122) First uroneural reaches: no uroneural present [0]; preural centrum 4 or 3 [1]; preural centrum 2 [2]; preural centrum 1 [3]; reaching no preural centrum [4].

117. Uroneurals extending forward beyond the 'second' ural centrum (diural terminology): no uroneural present [0]; three or four [1]; two [2]; one [3].

118. (124) Number of hypurals in adult individuals: eight or more than eight [0]; seven [1]; six or less [2]; all hypurals fused [3].

119. (125) Only hypural 2 (between the lower set of hypurals) fused with 'first' ural centrum (diural terminology): absent [0]; present [1].

120. Hypurals 1 and 2: independent from each other [0]; fused at their bases only [1]; fused to each other along their length [2].

121. (127) Both hypurals 1 and 2 associated by fusion or articulation with a 'compound centrum', apparently formed by preural centrum 1 and ural centrum(a): absent [0]; present [1].

122. (128) A space or diasteme between hypurals 2 and 3: absent [0]; present [1]; other condition: fusion of hypurals [2].

123. (129) First uroneural (pleurostyle) fused with a 'compound centrum' apparently formed by preural centrum 1 and ural centrum(a): absent [0]; present [1].

124. (130) Stegural: absent [0]; present [1].

125. (131) Membranous outgrowth of stegural covering laterally the ventral tips of epurals: absent [0]; present [1].

126. (132) Median caudal cartilage(s): absent [0]; present [1].

127. (133) Small 'urodermals' associated with the uppermost principal caudal fin ray(s): none [0]; two or three [1]; one [2]. (Modified from Arratia 2008a)

128. Fringing fulcra preceding the first principal caudal fin ray: many [0]; one to five [1]; absent [2].

129. (135) Epaxial basal fulcra on the dorsal magin of the caudal fin: present [0]; absent [1]. (Modified from Arratia 2008a).

130. (136) Proximity of the basal fulcra or dorsal precurrent (or procurrent) rays to: epurals and posterior uroneurals [0]; neural spines, epurals, and posterior uroneurals [1]; absence of structures [2].

131. (137) Long dorsal segmented precurrent (or procurrent) ray(s); absent [0]; present [1].

132. (138) Number of principal caudal rays: twenty or more [0]; nineteen [1]; less than nineteen [2].

133. (139) Lower lobe of the caudal fin with: no well-defined ventral lobe [0]; more than nine principal rays [1]; nine principal rays [2]; less than nine principal rays [3].
134. (140) Branched rays of the caudal fin: more than 16 [0]; 16 or less [1].

135. (141) Bases of the dorsalmost principal rays of the caudal fin crossing obliquely over the entire upper hypural series (save the last); present [0]; absent [1].

136. (142) Dorsal processes of the bases of the innermost principal caudal rays of upper lobe: absent [0]; present [1].

137. (143) Marginal principal caudal rays with: Z-like or step-like segmentation [0]; straight segmentation [1]. (Modified from Arratia 1991, 1996, 1997).

138. (144) One or more abdominal scutes, each of a single element, which crosses the ventral midline of the fish: absent [0]; present [1].

139. (145) Dorsal scute(s) preceding caudal fin: present [0]; absent [1].

140. (146) Amioid-type of scales or scales with radial structures (sensu Schultze 1996): absent [0]; present [1].

141. (147) Lepidosteoid-type of scales (sensu Schultze 1996): absent [0]; present [1].

142. (148) Cycloid scales: absent [0]; present [1]; other condition: without scales [2].

143. (149) Cycloid scales posterior to the pectoral girdle with circuli crossed by transverse lines in the middle field: absent [0]; [present [1]; other condition: without scales [2].

144. (150) Cycloid scales with crenulate posterior margin: absent [0]; present [1]; other condition: without scales [2].

145. (151) Leptocephalous larva: absent [0]; present [1].

146. (152) Separation between olfactory organ and eye: narrow [0]; broad [1].

147. (153) Primary olfactory lamellae bearing secondary lamellae: present [0]; absent [1].

148. (154) Adipose fin: absent [0]; present [1].

149. (155) Primary bite between parasphenoid and basihyal: absent [0]; present [1]. (Li \& Wilson 1996).

150. (156) Intestine coiling to left of stomach: absent [0]; present [1]. (Nelson 1969).

151. (157) Posterior margin of maxilla: concave or at least notched [0]; convexly rounded or straight [1]; sharp [2]. (Modified from Grande \& Bemis 1998).

152. (158) Symplectic: articulates with lower jaw [0]; does not articulate with lower jaw [1]. (Patterson 1973).

153. (159) Solid perichondrally ossified diplospondylous centra in adult individuals: absent [0]; present [1].

154. (160) Posterior margin of caudal fin convexly rounded: absent [0]; [present [1].

155. (161) Number of ossified ural neural arches: more than two [0]; two [1]; one or none [2].

156. (162) Arrangements of hypurals and caudal fin rays: each hypural normally articulates with one caudal ray [0]; each hypural normally articulates with a few caudal rays [1]; fusion of hypurals [2]. (Modified from Grande \& Bemis 1998).

157. (163) Number of independent ural centra (in adults): more than two [0]; two or one [1]; no ural centra [2]. (Modified from Patterson 1977; Pinna 1996).

158. (164) First two hypurals supported by a single centrum: absent [0]; present [1]; fusion of elements [2]. (Modified from Patterson 1977; Pinna 1996).

159. (165) Only ural neural arches modified as uroneurals: absent [0]; present [1]. (Modified from Patterson 1973, 1977; Pinna 1996).

160. (166) Two ossified hypohyals: absent [0]; present [1]. (Arratia \& Schultze 1990).

161. (167) Urohyal formed as an unpaired tendon-bone: absent [0]; present [1]. (Arratia \& Schultze 1990; Pinna 1996).

162. (170) Premaxilla: without mobility [0]; with certain mobility [1]; mobile [2]. (Modified from Patterson \& Rosen 1977; Pinna 1996). 
163. (171) Coronoid bones in lower jaw: present [0]; absent [1]. (Patterson 1977; Pinna 1996).

164. (172) Surangular bone in lower jaw: present [0]; absent [1].

165. (173) Posterior myodome: not extending into basioccipital (e.g., in prootic) [0]; extending in basioccipital [1]; absent [2]. (Modified from Patterson 1977; Pinna 1996).

166. (174) Vomer (in adults): paired [0]; unpaired [1]. (Modified from Patterson 1977; Pinna 1996).

167. (176) Craniotemporal muscle: absent [0]; present [1]. (Stiassny 1986; Pinna 1996)

168. (177) Accessory nasal sacs: absent [0]; present [1]. (Chen \& Arratia 1994; Pinna 1996).

169. (178) Four proximal pectoral radials: absent [0]; present [1]. (Jessen 1972; Patterson 1977; Pinna 1996).

170. (179) Premaxillae forming a rostral tube that projects into the ethmoidal region: absent [0]; present [1]. (Brito 1997).

171. (180) Presence of toothed predentary: absent [0]; present [1] (Brito 1997).

172. (181) Very posterior position of the preopercular sensory canal in a peculiarly shaped preopercle: absent [0]; present [1]. (Brito 1997).

173. (182) Interopercular bone: present [0]; absent [1]. (Brito 1997; Arratia 1999)

174. (183) An occipital process formed by fusion of intercalar and autopterotic absent [0]; present [1]. (Brito 1997).

175. (186) Large compound rostrodermethmoid meeting the parietal bones (so-called frontals) posteriorly, and separating the paired premaxillae and nasal bones: absent [0]; present [1]. (Mainwaring 1978).

176. (187) Pectoral fin scythe-like and rays branching at their extreme ends: absent [0]; present [1]. (Mainwaring 1978).

177. (188) Large, roofed posttemporal fossa framed by the epiotic, pterotic, exoccipital, and intercalar: absent [0]; present [1].
178. (189) Large, well-developed extrascapular bone extending caudally close to the posterior margin of opercle: absent [0]; present [1].

179. (190) Circumorbital ring: incompletely closed [0]; completely closed ring, no space left between bones [1].

180. (191) Dermosphenotic: small [0]; very large, well-developed bone [1].

181. (192) Independent antorbital bone: present [0]; absent [1].

182. (193) Posterior infraorbital bones: small and not overlapping or slightly overlapping the anterior margin of preopercle [0]; expanded posterior infraorbitals overlapping the anterior margin of preopercle [1].

183. (194) Condition of skull roof: mediopostparietal [0]; lateropostparietal [1]. (Cavin 2001, but following the terminology based on homologization of skull roof bones).

184. Elongate maxilla bearing numerous villiform teeth: absent [0]; present [1]

185. Maxilla with a ventral margin: straight or almost straight [0]; slightly convex [1]; slightly concave [2].

186. Quadrate with an almost straight upper margin extending anterodorsally above the ectopterygoid: absent [0]; present [1].

187. Number of independent pharyngobranchials (bone/cartilage): three [0]; four [1].

188. Reticulated scales: absent [0]; present [1].

189. Laterally expanded and subrectangular dorsal scutes each of which bears a median keel: absent [0]; present [1].

190. Scaphium: absent [0]; present [1].

191. Tripus: absent [0]; present [1].

192. Autopalatine ossification: absent [0]; present [1].

193. Uroneurals cover the lateral faces of the ural centra and first two preural centra: absent [0]; present [1]. (Patterson \& Rosen 1977). 